Review Article

\title{
The Possible Therapeutic Effects of Some Medicinal Plants for Chronic Cough in Children
}

\author{
S. Gholamreza Mortazavi Moghaddam, ${ }^{1}$ Majid Kianmehr, ${ }^{2}$ \\ and Mohammad Reza Khazdair $\mathbb{D}^{1}$ \\ ${ }^{1}$ Cardiovascular Diseases Research Center, Birjand University of Medical Sciences, Birjand, Iran \\ ${ }^{2}$ Esfarayen Faculty of Medical Sciences, Esfarayen, Iran \\ Correspondence should be addressed to Mohammad Reza Khazdair; m.khazdair@yahoo.com
}

Received 9 May 2020; Revised 17 August 2020; Accepted 19 September 2020; Published 1 October 2020

Academic Editor: Andresa A. Berretta

Copyright (c) 2020 S. Gholamreza Mortazavi Moghaddam et al. This is an open access article distributed under the Creative Commons Attribution License, which permits unrestricted use, distribution, and reproduction in any medium, provided the original work is properly cited.

\begin{abstract}
The use of plants or their isolated bioactive components for the prevention and treatment of various disorders has been developed. Here, we aim to identify effective medicinal plants for relief of cough and respiratory symptoms in children. The data of this review article were obtained from published articles in scientific databases, including PubMed, Google Scholar, and Scopus, until December 2019. The keywords, including "Zataria multiflora Boiss." OR "Portulaca oleracea L." OR "Ferula assa-foetida L." OR "Nigella sativa L." AND "respiratory symptoms" OR "airway inflammation" OR "smooth muscle relaxant effects," were searched individually or combined. The mentioned medicinal plants decreased total white blood cell (WBC), neutrophils, and eosinophils counts of blood and lung lavage in animal model-induced respiratory disorders. These plants also have protective effects on serum immunoglobulin, antibody titer, eosinophil count, and proinflammatory cytokines. Evidence from the studies indicated that the abovementioned medicinal plants have smooth muscle relaxant properties (bronchodilator effects) via stimulation of $\beta$-adrenoceptor or inhibition of muscarinic receptors (in vitro) and also improved the pulmonary function test in clinical settings. These medicinal plants are safe and easy to use. Based on the anti-inflammatory, anti-antispasmodic, and immunomodulatory effects, the clinical benefit may be assumed, therefore considering a place for these medicinal plants in relieve of chronic cough and symptoms of children's allergy, asthma, and common cold.
\end{abstract}

\section{Introduction}

Common cold is a kind of mild and self-limited respiratory illness caused by several different viruses [1]. Influenza virus is prevalent in winter, which affects a wide people in community. Influenza infection may lead to bacterial infections such as sinusitis, bronchitis, and pneumonia. People with declining immune systems or immune deficiency disorders and also children less than three years old make up high risk groups [2]. Cough is one of the most common symptoms of upper respiratory tract infection, specially in children [3]. It has been reported that a cough is defined as acute cough after <14-day duration, while definition for chronic cough varied from 3- to more than 12 -week duration [4]. Cough in children causes significant anxiety to parents, and the use of incorrect or unnecessary drugs for cough treatment is related to adverse events [5]. Different class of drugs have been used for symptomatic treatment of cough, including antihistamines, decongestants, expectorants, mucolytics, and bronchodilators [6].

It should be noted that a significant number of antitussive drugs were obtained from natural products and plants in ancient times. Herbal medicines are popular in most of countries, and people who have used them possess valuable information about these plants $[7,8]$. For this reason, the use of these drugs in outpatient treatments has been of great interest and so accepted by most of people. However, proper use of medicinal plants requires a lot of knowledge and experience, which has been unfortunately distorted over time $[9,10]$. In Iranian traditional medicine, 
Zataria multiflora Boiss. was used for the treatment of various disorders, including remedy of coughs due to colds, oral cavity infection, dyspepsia, and also an antibacterial agent $[11,12]$. Portulaca oleracea $\mathrm{L}$. is a plant cold in nature and sour in taste, which is used to cool the blood and also used for treatment of fever, dysentery, diarrhea, eczema, and hematochezia in Chinese traditional medicine $[13,14]$.

Furthermore, this plant is used traditionally for gastrointestinal diseases, respiratory problems, and liver inflammation [15]. Ferula assa-foetida L. is usually used for the treatment of cough and pneumonia and gastrointestinal parasites and also as an anticoagulant $[16,17]$. Nigella sativa seeds are used as a diuretic, liver tonic, and digestive. This plant is also used traditionally for the treatment of diarrhea, dyspnea, headache, influenza, and cough in the Middle East, India, and Pakistan [18].

This study aimed to search scientific database and identify the medicinal plants used as a spice and food additive in treatment of cold and cough.

\section{Pharmacologic Mediations for the Treatment of Chronic Cough}

2.1. Anti-Inflammatory Drugs. Combination of anti-inflammatory drugs and acetaminophen seem to be effective in relieving pain and fever in patients with upper respiratory tract infection [19].

2.2. Antihistamines Drugs. Antihistamines as monotherapy have no significant effect on the treatment of cold and cough [20]. Antihistamines, combined with decongestants, have a mild to moderate impact on common cold in older children and adults [21].

2.3. Antiviral Drugs. Among a large number of common cold viruses, rhinoviruses are the most common [22]. The antiviral drugs share a common mechanism of action, binding to specific hydrophobic pockets in virion capsid and inhibiting virion attachment or uncoating [23]. On the other hand, numerous studies have showed that different types of antiviral drugs have no effect against rhinovirus in clinical setting $[24,25]$.

2.4. Bronchodilator Drugs. Medications used to relieve acute respiratory symptoms induced by cold as well as asthma include short-acting bronchodilators [26], long-acting $\beta$-agonists [27], or the combination of long-acting $\beta$-agonists and inhaled corticosteroid [28, 29].

\section{Results}

3.1. Traditional and Phytomedicine Uses of Plants. Phytomedicine is defined as the use of plants or their isolated chemical components for the prevention and treatment of various disorders [30]. Plants or natural product agents were used since ancient times for treatment or control of various diseases; however, the use of herbal medicine has increased in recent decades. According to the World Health
Organization reports, approximately $80 \%$ of the population of developing countries, currently, believed that phytomedicines are an affordable source of medication [31]. Plants contain numerous bioactive compounds in which many of them showed antimicrobial properties [32]. Plant-derived medicines have been part of folk healthcare in the most parts of the world for hundreds of years, and there is increasing interest in plants as sources of agents to fight microbial diseases in modern countries [33].

3.2. Zataria multiflora Boiss. Zataria multiflora Boiss. (Z. multiflora), which belongs to the Lamiaceae family, has been traditionally used as an anesthetic, antispasmodic [34], antiseptic, antidiarrheal, and analgesic agents [35]. The neuroprotective effect of $Z$. multiflora (used as a spice) was also reported [36]. Antioxidant, anti-inflammatory, and immunomodulatory properties of $Z$. multiflora and its constituents have already been reported [37]. This plant has also been used for treatment of dyspepsia and bloating [12] as well as vomiting, headache, migraine, premature labor pain, and common cold [38]. One study about essential oils extracted from $Z$. multiflora revealed its inhibitory effect on growth of yeasts and also antimicrobial activities against Gram-positive and negative bacteria at 0.12 to $8 \mu \mathrm{L} / \mathrm{mL}$ concentrations [39].

3.2.1. Anti-Inflammatory Effects. Therapeutic effects of Z. multiflora on inflammation in the lung and remedy of cough due to colds have been reported in traditional medicine [40]. The hydroethanolic extract of $Z$. multiflora decreased total white blood cell (WBC), neutrophils, and eosinophils counts in the animal model-induced chronic obstructive pulmonary disease (COPD) [41]. The beneficial effects of $Z$. multiflora extract on tracheal responsiveness and emphysema in the animals model of COPD have also been reported [42]. Moreover, there are reports about the protective effects of $Z$. multiflora on total and differential WBC in bronchoalveolar lavage fluid (BALF) as well as on lung pathology, serum levels of phospholipase A2 (PLA2), total protein, and histamine of ovalbumin- (OVA-) sensitized animals [43]. What follows from these findings is that $Z$. multiflora has probably potential therapeutic effects on respiratory disorders associated with inflammation in the lung, such as asthma and COPD.

The aqueous and ethanolic extracts of $Z$. multiflora $(0.08$ and $1.4 \mathrm{~g} / \mathrm{kg}$, respectively) showed antinociceptive activities against xylene $(0.03 \mathrm{ml})$ induced acute and acetic acid-induced $(0.7 \%$, i.p.) chronic inflammation [44]. Intraperitoneal administration of hydroalcoholic extract and essential oil of Z. multiflora $(500 \mathrm{mg} / \mathrm{kg}$, and $0.3 \mathrm{~mL} / \mathrm{kg}$, i.p., respectively) showed antinociceptive effects in the acetic acidinduced writhing test in rats [45]. It may be concluded that the extract of $Z$. multiflora has antinociceptive effects mediated by its anti-inflammatory property.

The methanolic extracts of $Z$. multiflora significantly decreased the macroscopic and microscopic scores in inflammatory bowel diseases (IBD) induced by intrarectal administration of acetic acid $(0.1 \mathrm{ml})$ [46]. 
Pretreatment of LPS-stimulated murine macrophages with essential oils extracted from Z. multiflora, including $52 \%$ carvacrol, $16 \%$ thymol, and $10 \%$ p-cymene, leads to a significant reduction in $\mathrm{H}_{2} \mathrm{O}_{2}$ and nitric oxide (NO) production. This effect is mediated by inhibition of oxidative stress process or by radical scavenging activity of phenolic groups of the essential oil such as thymol and carvacrol. Therefore, Z. multiflora extract or its essential oil can be used in the therapy of oxidative damage induced by inflammation [47]. The findings prove that $Z$. multiflora has potential of reduction in inflammation by reduce in $\mathrm{H}_{2} \mathrm{O}_{2}, \mathrm{NO}$, differential $\mathrm{WBC}$, and phospholipase $\mathrm{A} 2$ production.

3.2.2. Relaxant Effect on Tracheal Smooth Muscle. The therapeutic effect of $Z$. multiflora in respiratory disorders of chemical war victims [48] and its antitussive effect were suggested, which could be due to its relaxant effect on airway smooth muscle leading to bronchodilation [49].

Long-term administration of $Z$. multiflora hydroethanolic extract also caused a reduction in tracheobronchial hyperresponsiveness in animal model of asthma [43] and COPD [42]. The possible antagonistic effect of the hydroethanolic extract of $Z$. multiflora on muscarinic receptors of incubated tracheal chains with propranolol and chlorpheniramine versus to those of nonincubated tissue was investigated [50].

The inhibitory effects of $Z$. multiflora on histamine (H1) receptors of the incubated trachea with $1.4 \mu \mathrm{M}$ indomethacin and $1 \mu \mathrm{M}$ propranolol versus to those of nonincubated tissue were reported [51]. In a similar study, Z. multiflora extract (2.5, 5 , and $10 \mu \mathrm{g} / \mathrm{mL})$ and carvacrol $(1,2$, and $4 \mu \mathrm{g} / \mathrm{mL})$ showed also inhibitory effect on histamine $\left(\mathrm{H}_{1}\right)$ receptors [52]. The stimulatory effects of $Z$. multiflora on $\beta 2$-adrenoceptor receptors of incubated guinea pig tracheal smooth muscle with isoprenaline versus to those of nonincubated tissue were reported [53].

The inhibitory effects of $Z$. multiflora extract on voltagedependent calcium channels of the ileum smooth muscle were also reported $[54,55]$.

KCL but not acetylcholine induced uterus muscle contraction was reversed by $Z$. multiflora extract $(2 \mathrm{mg} / \mathrm{ml})$ which is more potent than the atropine effect [54]. Because $\mathrm{KCl}$ induced muscle contraction is mediated by voltagedependent calcium channel, these findings support a calcium channel blocking effect for the Z . multiflora extract.

Carvacrol has an inhibitory effect on L-NAME induced hypertension mediated by cardiac L-type calcium channel blocking action [56].

In conclusion of the referred studies, Z. multiflora reduces inflammation in the respiratory system and also declines smooth muscle contraction by action on various tracheal smooth muscle receptors, which lead to a relaxant effect. Therefore, the use of this plant may be useful for obstructive airway disorders, including asthma and COPD. The anti-inflammatory and smooth muscle relaxant effects of $Z$. Multiflora are summarized in Table 1 .

3.2.3. Clinical Evidences. Z. multiflora and its main constituent, carvacrol, reduce inflammatory and oxidant markers and increase antioxidant markers and improve pulmonary function tests (PFT) in patients who were exposed to sulfur mustard in past (SM) and suffered from lung injuries $[57,58]$. Z. multiflora syrup (5 and $10 \mathrm{mg} / \mathrm{kg} /$ day) and carvacrol $(1.2 \mathrm{mg} / \mathrm{kg} /$ day $)$ significantly reduce chest wheeze in asthmatic patients. In addition, Z. multiflora and carvacrol both significantly increase forced expiratory volume in 1 second $\left(\mathrm{FEV}_{1} \%\right)$ and decrease the plasma level of $\mathrm{NO}^{2-}$ after two months of treatment [59].

Two-month treatment with Z. multiflora extracts (5 and $10 \mathrm{mg} / \mathrm{kg} /$ day) significantly decreases serum levels of inflammatory cytokines, including IL-2, IL-6, and IL-8; it also significantly raises serum levels of IL- 10 and IFN- $\gamma$ in patients exposed to SM. Furthermore, Z. multiflora increases maximum midexpiratory flow (MMEF) and maximum expiratory flow at 25,50 , and $75 \%$ of vital capacity (VC) (MEF25, 50, and 75) of treatment [60].

A similar study showed that $Z$. multiflora was able to significantly lower serum levels of tumor necrosis factor (TNF- $\alpha$ ), monocyte chemotactic protein 1 (MCP-1), vascular endothelial growth factor (VEGF), and epidermal growth factor (EGF) and also improve PFT test values and respiratory symptoms in the SM exposed patients [61]. In addition, $Z$. multiflora (5 and $10 \mathrm{mg} / \mathrm{kg} /$ day) significantly improves clinical symptoms, PFTs values, oxidative stress, and cytokine levels in asthmatic patients two months after treatment compared to baseline [62]. Taken together, these studies confirm the efficacy of $Z$. multiflora for prevention and treatment of respiratory disease in adults and children.

3.3. Portulaca oleracea L. Portulaca oleracea L. (P. oleracea), or Purslane from Portulacaceae family, is an annual and grassy plant with small yellow flowers, which grows in different parts of the world including Europe, Indies, China, Japan, and Iran [63]. P. oleracea contains omega 3 fatty acids and alpha-linolenic acid more than other leafy vegetable plants [64]. Antitussive [65], analgesic, and anti-inflammatory [66], as well as the neuroprotective, effect of $P$. oleracea were reported [36]. The ethanol extracts of $P$. oleracea $(40 \mathrm{mg} / \mathrm{mL})$ showed antimicrobial properties against five bacteria and three fungi by agar diffusion method [67].

3.3.1. Anti-Inflammatory Effects. The hydroethanolic extracts $(10,40$, and $160 \mu \mathrm{g} / \mathrm{ml})$ of $P$. oleracea significantly increases anti-inflammatory cytokine (IFN- $\gamma$ ) in nonstimulated and stimulated human lymphocytes cells. In stimulated lymphocytes, the extract of $P$. oleracea significantly decreases inflammatory cytokines such as IL-4, IL-10, and free radicals such as NO [68]. The aqueous extracts of P. oleracea $(10,25,50$, and $100 \mu \mathrm{g} / \mathrm{ml})$ in a dose-dependent manner significantly inhibit TNF- $\alpha$-induced intracellular reactive oxygen species (ROS) production. $P$. oleracea also suppressed the TNF- $\alpha$-induced degradation of $\mathrm{I} \kappa \mathrm{B}-\alpha$ and reduces the TNF- $\alpha$-induced NF- $\kappa$ B binding protein in the vascular endothelial cells. The plant extracts also effectively reduce the mRNA expression of monocyte chemoattractant protein 1 (MCP-1) and IL-8 induced by TNF- $\alpha$ [69]. The 
TABle 1: Anti-inflammatory and smooth muscle relaxant effects of Z. multiflora.

\begin{tabular}{|c|c|c|c|c|}
\hline Extract & Doses & Model of study & Effects & Reference \\
\hline \multirow{5}{*}{ Aqueous ethanolic } & $\begin{array}{l}\text { 0.4, } 0.8 \text {, and } 1.6 \mathrm{mg} / \mathrm{ml} \text {, } \\
\text { p.o. }\end{array}$ & $\begin{array}{l}\text { Guinea pigs model of } \\
\text { COPD }\end{array}$ & $\begin{array}{l}\text { Improved the levels of IL-8, total WBC number, } \\
\text { and lymphocytes percentage }\end{array}$ & {$[41]$} \\
\hline & $0.4,0.8$ and $1.6 \mathrm{mg} / \mathrm{ml}$ & $\begin{array}{l}\text { Guinea pigs model of } \\
\text { COPD }\end{array}$ & $\begin{array}{c}\text { Improved tracheal responsiveness (TR) and } \\
\text { emphysema }\end{array}$ & {$[42]$} \\
\hline & $\begin{array}{l}0.2,0.4 \text {, and } 0.8 \mathrm{mg} / \mathrm{ml} \text {, } \\
\text { p.o. }\end{array}$ & $\begin{array}{l}\text { Guinea pigs model of } \\
\text { asthma }\end{array}$ & $\begin{array}{c}\text { Reduced tracheal responsiveness to } \\
\text { methacholine and OVA, serum levels of NO, } \\
\text { nitrite, and PLA2 }\end{array}$ & {$[43]$} \\
\hline & $0.2,0.8$ and $1.4 \mathrm{~g} / \mathrm{kg}$, i.p. & $\begin{array}{l}\text { Mice model of paw } \\
\text { inflammation }\end{array}$ & Inhibited acute inflammation & {$[44]$} \\
\hline & $0.2,0.8$ and $1.4 \mathrm{~g} / \mathrm{kg}$, i.p. & $\begin{array}{l}\text { Rat model of paw } \\
\text { inflammation }\end{array}$ & Inhibited chronic inflammation & {$[44]$} \\
\hline $\begin{array}{l}\text { Aqueous ethanolic and } \\
\text { essential oil }\end{array}$ & $\begin{array}{l}500 \text { and } 900 \text { and } \\
\text { essential oil } 0.3 \mathrm{ml} / \mathrm{kg} \text {, } \\
\text { i.p. }\end{array}$ & Tail flick test & Showed anti-inflammatory effect & {$[45]$} \\
\hline Aqueous methanolic & $\begin{array}{l}\text { 400, } 600,900 \text { p.p.m. in } \\
\text { drinking water }\end{array}$ & $\begin{array}{l}\text { Albino mice model of } \\
\text { bowel inflammation }\end{array}$ & $\begin{array}{l}\text { Reduced score of macroscopic and microscopic } \\
\text { characters acetic acid-treated group }\end{array}$ & {$[46]$} \\
\hline Aqueous ethanolic & 5 and $10 \mathrm{mg} / \mathrm{kg}$ & SM exposed patients & $\begin{array}{c}\text { Reduced inflammatory and oxidant markers, but } \\
\text { improved PFT values }\end{array}$ & {$[57,58]$} \\
\hline $\mathrm{Aqu}$ & Un & SM & Showed bronchodilatory effects & [48] \\
\hline Hydroethanolic & $0.2,0.4$ and $0.8 \mathrm{mg} / \mathrm{ml}$ & Sensitized Guinea pigs & Reduced tracheal responsiveness & {$[43]$} \\
\hline Hydroethanolic & $(0.4,0.8$ and $1.6 \mathrm{mg} / \mathrm{ml})$ & $\begin{array}{l}\text { Guinea pigs model of } \\
\text { COPD }\end{array}$ & Relaxed tracheal smooth muscle & {$[42]$} \\
\hline Hydroethanolic & $2.5,5$, and $10 \mu \mathrm{g} / \mathrm{mL}$ & Tracheal chains & $\begin{array}{c}\text { Showed antagonistic effects on muscarinic } \\
\text { receptors }\end{array}$ & {$[50]$} \\
\hline Hydroethanolic & $2.5,5$, and $10 \mu \mathrm{g} / \mathrm{mL}$ & Tracheal chains & $\begin{array}{l}\text { Showed inhibitory effects on histamine }(\mathrm{H} 1) \\
\text { receptors }\end{array}$ & {$[51]$} \\
\hline Hydroethanolic & $2.5,5$, and $10 \mu \mathrm{g} / \mathrm{mL}$ & Tracheal chains & $\begin{array}{l}\text { Showed stimulatory effects on } \beta 2 \text {-adrenoceptor } \\
\text { receptors }\end{array}$ & {$[53]$} \\
\hline Hydroalcoholic extract & 1 and $2 \mathrm{mg} / \mathrm{ml}$ & Ileum smooth muscle & $\begin{array}{c}\text { Showed inhibitory effect on voltage dependent } \\
\text { calcium channels }\end{array}$ & {$[54]$} \\
\hline Hydroalcoholic extract & $2 \mathrm{mg} / \mathrm{ml}$ & Uterus muscle & Showed calcium channels blocking effect & [54] \\
\hline
\end{tabular}

TR, tracheal responsiveness; NO, nitric oxide; IL- $1 \beta$, interleukin- $1 \beta$; BAL, bronchoalveolar lavage; PFT, pulmonary function tests; SM, sulfur mustard; COPD, chronic obstructive pulmonary disease.

ethanol extract of $P$. oleracea inhibited the production of inflammatory mediators such as $\mathrm{NO}$ and proinflammatory cytokines, including TNF- $\alpha$, IL- $1 \beta$, and IL- 6 in LPS-induced inflammation in RAW 264.7 cells (derived from BALB/c mice). $P$. oleracea extracts also inhibited the phosphorylation of (ERK1/2), c-Jun $\mathrm{NH}_{2}$-terminal kinase (JNK), and NF- $\kappa \mathrm{B}$ activation in cells [70]. POL-P3b as a polysaccharide fraction purified extracted from $P$. oleracea upregulates the expression of CD80, CD86, and CD83 and stimulates production of IL-12 and TNF- $\alpha$ in large quantities and IL-10 in small quantities by improving the maturation and function of murine bone-marrow-derived dendritic cells (DCs). Furthermore, POL-P3b significantly increased the expression of Toll-like receptor 4 (TLR-4) on DCs treated. The findings confirm that POL-P3b is able to induce DCs maturation through TLR-4 [71]. The oral administration of $P$. oleracea polysaccharides significantly and dose-dependently increases stimulation indices (SI) of $\mathrm{T}$ lymphocytes and $\mathrm{B}$ lymphocytes in Wistar rats [72]. The polysaccharide (POP) from $P$. oleracea shows the preventive effect on the reduction of the spleen weight and the number of murine spleen T cells after 30 days of inducing age in the mice with D-galactose [73]. $P$. oleracea $(50-200 \mathrm{mg} / \mathrm{kg})$ significantly reduces IL- $\beta$, IL-6, TNF- $\alpha, \mathrm{PGE}_{2}$, and TGF- $\beta$ and increases IL-10 levels in the bronchoalveolar lavage fluid (BALF) of lung treated by lipopolysaccharide- (LPS-) induced inflammation [74].

3.3.2. Relaxant Effect on Tracheal Smooth Muscle. The relaxant effect of $P$. oleracea on skeletal muscle [75] and smooth muscle [76] has been shown. The hydroethanolic extract of $P$. oleracea showed a stimulatory effect on $\beta$-adrenoceptor in the tracheal smooth muscles of guinea pigs [77]. The relaxant effect of $P$. oleracea on tracheal smooth muscles via the blocking of the muscarinic receptor was also investigated [78]. The researchers suggested that bronchodilatory effects of $P$. oleracea can be attributed to a variety of mechanisms, including $\beta_{2}$-adrenoceptors stimulation [79], strengthening the inhibitory effect of nonadrenergic and noncholinergic nervous system [76], opening potassium channels [80], inhibition of phosphodiesterase [81], and calcium channel antagonism in tracheal chain [82]. Ethyl acetate (EA) of P. oleracea extract has been indicated to decrease intestinal motility in ICR mice compared to those treated with acetylcholine [83]. Based on the conducted studies, the aqueous extract of $P$. oleracea has been shown to enhance acetylcholine (Ach) and sodium nitroprusside (SNP) induced vascular relaxation of aortic rings in diabetic 
mice. The created effect is associated with a significant reduction in the level of vasoconstrictor endothelin- (ET-) 1. It has also been suggested that the aqueous extract of $P$. oleracea suppresses overexpression of vascular cell adhesion molecule- (VCAM) 1, intracellular cell adhesion molecular- (ICAM) 1, E-selectin, and matrix metalloproteinase (MMP) 2 in aortic tissue in $\mathrm{db} / \mathrm{db}$ mice [84].

Aqueous extract of $P$. oleracea reduced the peristaltic index by antagonistic effects on calcium channel in the isolated guinea pig ileum strip [85]. The aqueous extract of the plant also showed a relaxant effect on smooth muscle of vasculatures, guinea pig fundus, rabbit jejunum, and rabbit aorta [86]. Therapeutic effect of $P$. oleracea in the airway of asthmatic patients showed that the oral admonition of $5 \%$ boiled extract $(0.25 \mathrm{ml} / \mathrm{kg})$ improved pulmonary function tests similar to theophylline [76].

Based on the referred studies, the $P$. oleracea has inhibitory effect on smooth muscle contraction, cytokine production, and inflammation in the respiratory system that may be useful for obstructive airway disorders, including asthma and COPD. The anti-inflammatory and smooth muscle relaxant effects of $P$. oleracea are presented in Table 2.

3.3.3. Clinical Evidences. Bronchodilatory effect of the boiled extract of $P$. oleracea in asthmatic patients was revealed by enhanced all measured PFTs. It has also been reported that this bronchodilatory effect is equivalent to theophylline syrup [76]. Taking $P$. oleracea seeds ( $5 \mathrm{~g}$ ) twice a day significantly decreases serum levels of lipid profiles and fasting blood glucose in subject with type 2 diabetes [87].

Topical administration of $P$. oleracea aqueous extract $(140 \mathrm{mglml})$ in patient with incomplete injury of the spinal cord (T6) significantly reduced muscle spasm more than $50 \%$. Reductions in tone were recorded in some patients with flexor or extensor contractures [88].

Daily supplement of $P$. oleracea (7.5 grams) for 8 weeks in type 2 diabetic women significantly reduced matrix metalloproteinases 2 and 9 (MMP2 and MMP9) and tissue inhibitor of matrix metalloproteinase (TIMP1) [89].

3.4. Ferula assa-foetida L. Ferula assa-foetida L. (F. assafoetida L.) or asafoetida belongs to the Apiaceae family. Its gum resin is obtained from the exudates of the living underground rhizome or taproots of the plant. F. assa-foetida or gum-resin is known as "Anghouzeh," "Khorakoma," and "Anguzakoma" in Iran [90]. One conducted study revealed that the sesquiterpene coumarins, isolated from $\mathrm{CHCl} 3-$ soluble extract of $F$. assa-foetida, showed higher potency against the influenza A virus (H1N1) (IC50 0.26-0.86 $\mu \mathrm{g}$ / $\mathrm{mL}$ ) than amantadine (IC50 $0.92 \mu \mathrm{g} / \mathrm{mL})$ [91].

3.4.1. Anti-Inflammatory Effects of F. assa-foetida. The roots, young shoots, and leaves of $F$. assa-foetida are eaten as a vegetable. Leaves of the plant possess anthelmintic, carminative, and diaphoretic properties and the root of the plant are used as antipyretic [92]. F. assa-foetida is also used for the treatment of various inflammatory diseases, including asthma, stomachache, flatulence, intestinal parasites, poor digestion, and influenza in traditional medicine [91]. Furthermore, previous recent study also reported that oleogum resin of F. assa-foetida possesses sedative, expectorant, analgesic, antidiabetic, antispasmodic, anti-inflammatory, and antiepileptic effects [93]. The oleogum resin of F. assa-foetida also showed antioxidant, antiviral, antifungal, antispasmodic, and antihypertensive effects in pharmacological studies [90]. It has been documented that F. assa-foetida resin can potentially inhibit monoamine oxidase B (MAO$B$ ), and it can be used in the therapy of neurodegenerative diseases such as Parkinson's and Alzheimer's diseases [94].

3.4.2. Relaxant Effect on Tracheal Smooth Muscle. The relaxant effect of aqueous extract of $F$. assa-foetida (2, 5, and $10 \mathrm{mg} / \mathrm{ml}$ ) on the smooth muscle of the guinea pig tracheal chain (in vitro study) was reported [95]. The relaxant effect of $F$. assa-foetida extract via inhibitory effect on histamine (H1) receptors, muscarinic receptors, and possible mechanisms for functional antagonistic on tracheal smooth muscle) have been investigated and $[96,97]$ also reviewed [98].

The inhibitory effect of ethanolic root extract of the Ferula genus (Ferula sinaica) on rabbit tracheal contraction induced by acetylcholine and also guinea pig uterine smooth muscle contractions induced by oxytocin have been reported [99]. In a similar study, Ferula sinaica (50 mg) inhibited the histamine $\left(10^{-4} \mathrm{M}\right)$ induced contractions of guinea pig tracheal smooth muscle [100].

The relaxant effects of $F$. assa-foetida and its main constituents (umbelliprenin) on the tracheal smooth muscle contracted by methacholine and KCL were also reported [101]. It has been reported that $F$. assa-foetida extract $(1-7 \mathrm{mg} / \mathrm{ml})$ reduces the spontaneous contraction of the isolated guinea-pig ileum and also contraction induced by $\mathrm{KCl}(28 \mathrm{mM})$, acetylcholine $(20 \mu \mathrm{M})$, and histamine $(20 \mu \mathrm{M})$. Extract of the plant $(3 \mathrm{mg} / \mathrm{ml})$ has antagonists property in guinea-pig isolated ileum precontracted with $\mathrm{KCl}$ and also has cyclooxygenase inhibitor property [102]. F. assa-foetida seed's essential oil $(0.1,0.2$, and $0.3 \%)$ showed antispasmodic action on isolated rat's ileum contraction induced by acetylcholine [103]. F. assa-foetida extract ( $2.2 \mathrm{mg} / 100 \mathrm{~g}$, b.w.) significantly reduces the mean arterial blood pressure in anesthetized rats [102]. In one study it was shown that F. sinaica root extract $(50 \mathrm{mg})$ has inhibitory effects on rabbit aorta contractions induced by norepinephrine $\left(10^{-4} \mathrm{M}\right)$ [100]. Moreover, the vasodilatation property of $F$. assafoetida extracts $(180$ and $360 \mathrm{mg} / \mathrm{ml})$ on arterial rings was suggested [104].

The anti-inflammatory and smooth muscle relaxant effects of F. assa-foetida are reported in Table 3.

3.4.3. Clinical Evidences. The safety and efficacy of F. assafoetida on treatment of functional dyspepsia (FD) in a double-blinded, placebo-controlled study showed that treatment with $F$. assa-foetida $(250 \mathrm{mg} \times 2 /$ day $)(n=21)$ for 30 days significantly improved the overall score and quality of life compared to the placebo group. In addition, treatment 
TABLE 2: Anti-inflammatory and smooth muscle relaxant effects of P. oleracea.

\begin{tabular}{|c|c|c|c|c|}
\hline Extract & Doses & Model of study & Effects & Reference \\
\hline Hydroethanolic & $160 \mu \mathrm{g} / \mathrm{ml}$ & Lymphocyte & $\begin{array}{c}\text { Increased IL- } 4, \text { IL-10, IFN- } \gamma \text {, IFN- } \gamma / \text { il- } 4 \text {, and IL-10/il- } 4 \\
\text { ratios }\end{array}$ & {$[68]$} \\
\hline Aqueous extract & $100 \mu \mathrm{g} / \mathrm{ml}$ & Vascular endothelial cells & Decreased mRNA expressions of MCP-1 and IL- 8 & [69] \\
\hline Ethanol & $200 \mu \mathrm{g} / \mathrm{ml}$ & RAW 264.7 cells & Decreased TNF- $\alpha$, IL- $1 \beta$, and IL-6 & {$[70]$} \\
\hline POL-P3b & $(250 \mu \mathrm{g} / \mathrm{ml})$ & DCs & Increased IL-12 and IL-10 & {$[71]$} \\
\hline Polysaccharide & $600 \mu \mathrm{g} / \mathrm{ml}$, p.o. & Rat & Increased $\mathrm{T}$ lymphocytes and B lymphocytes & {$[72]$} \\
\hline Polysaccharide & Unknown & Mice & $\begin{array}{l}\text { Showed preventive effect on reduction of the spleen } \\
\text { weight and the number of murine spleen T cells }\end{array}$ & {$[73]$} \\
\hline Boiled extract & $0.25 \mathrm{mg} / \mathrm{kg}$ & Asthmatic patients & Increased measured PFTs & {$[76]$} \\
\hline $\begin{array}{l}\text { Aqueous } \\
\text { extracts }\end{array}$ & $\begin{array}{c}0.06,0.12 \text { and } \\
0.25 \mathrm{mg} / \mathrm{ml}\end{array}$ & Tracheal chains of guinea pig & Showed stimulatory effect on $\beta$-adrenoceptor & {$[77]$} \\
\hline Hydroethanolic & $\begin{array}{l}0.25,0.50 \text { and } \\
1.00 \mathrm{mg} / \mathrm{ml}\end{array}$ & $\begin{array}{l}\text { Guinea pigs tracheal smooth } \\
\text { muscles }\end{array}$ & Showed blocking effects of muscarinic receptor & {$[78]$} \\
\hline $\begin{array}{l}\text { Ethanolic } \\
\text { extract }\end{array}$ & $(250 \mu \mathrm{g} / \mathrm{ml})$ & Mice & Reduced intestinal motility & {$[83]$} \\
\hline Aqueous extract & $\begin{array}{c}(300 \mathrm{mg} / \mathrm{kg} / \mathrm{day} \\
\text { po })\end{array}$ & Mice aortic tissue & $\begin{array}{c}\text { Suppressed overexpression of (VCAM) }-1 \text {, (ICAM) - 1, } \\
\text { E-selectin and (MMP) }-2\end{array}$ & {$[84]$} \\
\hline Aqueous extract & $600 \mu \mathrm{g} / \mathrm{ml}$ p.o. & Isolated guinea pig ileum strip & Reduced peristaltic index & {$[85]$} \\
\hline Aqueous extract & $7 \times 10^{-4} \mathrm{~g} / \mathrm{ml}$ & $\begin{array}{l}\text { Guinea pig fundus, rabbit } \\
\text { jejunum and rabbit aorta }\end{array}$ & $\begin{array}{l}\text { Showed relaxant effect on smooth muscle and reduced } \\
\text { blood pressure }\end{array}$ & {$[86]$} \\
\hline
\end{tabular}

IL: interleukin, IFN- $\gamma$ : interferon-gamma, POL-P3b: polysaccharide fraction, MCP-1: monocyte chemoattractant protein 1, TNF- $\alpha$ : tumor necrosis factor- $\alpha$, NO: nitrogen oxide, IgE: immunoglobulin E, (VCAM) 1: vascular cell adhesion molecule, (ICAM) 1: intracellular cell adhesion molecular, and (MMP) 2: matrix metalloproteinase.

TABLE 3: Anti-inflammatory and smooth muscle relaxant effect of $F$. assa-foetida.

\begin{tabular}{|c|c|c|c|c|}
\hline Extract & Doses & Model of study & Effects & Reference \\
\hline Root extract & Unknown & Traditional medicine & $\begin{array}{l}\text { Used for treatment of various inflammatory diseases including; } \\
\text { asthma, stomachache, flatulence, intestinal parasites, weak } \\
\text { digestion, and influenza. }\end{array}$ & [91] \\
\hline Oleo gum resin & $\begin{array}{l}50 \text { and } \\
100 \mathrm{mg} / \mathrm{kg}\end{array}$ & Seizures induced rat & $\begin{array}{c}\text { Showed antispasmodic, anti-inflammatory, and antiepileptic } \\
\text { effects. }\end{array}$ & {$[93]$} \\
\hline Oleo gum resin & Unknown & Traditional uses & $\begin{array}{c}\text { Showed antioxidant, antiviral, antifungal, antispasmodic, and } \\
\text { antihypertensive effects. }\end{array}$ & {$[90]$} \\
\hline $\begin{array}{l}\text { Aqueous } \\
\text { extract }\end{array}$ & $\begin{array}{l}2,5 \text { and } \\
10 \mathrm{mg} / \mathrm{ml}\end{array}$ & $\begin{array}{l}\text { Guinea pigs tracheal } \\
\text { smooth muscles }\end{array}$ & Showed relaxant effect on tracheal smooth muscle & {$[95]$} \\
\hline $\begin{array}{l}\text { Aqueous } \\
\text { extract }\end{array}$ & $\begin{array}{l}2,5 \text { and } \\
10 \mathrm{mg} / \mathrm{ml}\end{array}$ & $\begin{array}{l}\text { Guinea pigs tracheal } \\
\text { smooth muscles }\end{array}$ & $\begin{array}{l}\text { Showed competitive antagonistic effect at muscarinic receptors and } \\
\text { inhibitory effect on histamine (H1) receptors of tracheal smooth } \\
\text { muscles }\end{array}$ & {$[96,97]$} \\
\hline $\begin{array}{l}\text { Root ethanolic } \\
\text { extract }\end{array}$ & $50-500 \mathrm{mg}$ & Rat and guinea pig & $\begin{array}{l}\text { Inhibited the contractions of rabbit tracheal induced by } \\
\text { acetylcholine and contractions of guinea pig uterine smooth muscle } \\
\text { induced by oxytocin }\end{array}$ & [99] \\
\hline $\begin{array}{l}\text { Aqueous } \\
\text { extract }\end{array}$ & $\begin{array}{l}2,5 \text { and } \\
10 \mathrm{mg} / \mathrm{ml}\end{array}$ & $\begin{array}{l}\text { Guinea pigs tracheal } \\
\text { smooth muscles }\end{array}$ & Showed potent relaxant effect on tracheal smooth muscle & {$[101]$} \\
\hline $\begin{array}{l}\text { Aqueous } \\
\text { extract }\end{array}$ & $\begin{array}{l}1,2,3,5 \text { and } \\
7 \mathrm{mg} / \mathrm{ml}\end{array}$ & $\begin{array}{l}\text { Isolated guinea pig } \\
\text { ileum }\end{array}$ & $\begin{array}{c}\text { Reduced the spontaneous contraction of the isolated guinea-pig } \\
\text { ileum }\end{array}$ & {$[102]$} \\
\hline $\begin{array}{l}\text { Seed's essential } \\
\text { oil }\end{array}$ & $\begin{array}{l}0.1,0.2 \text { and } \\
0.3 \%\end{array}$ & Isolated rat's ileum & Showed antispasmodic effect on rat's ileum & [103] \\
\hline $\begin{array}{l}\text { Aqueous } \\
\text { extract }\end{array}$ & $\begin{array}{l}2.2 \mathrm{mg} / 100 \mathrm{~g} \\
\text { b.w }\end{array}$ & Rat & Reduced the mean arterial blood pressure & {$[102]$} \\
\hline Root extract & $50 \mathrm{mg}$ & Rabbit aorta & $\begin{array}{c}\text { Showed inhibitory effects on contractions of rabbit aorta induced by } \\
\text { norepinephrine }\end{array}$ & {$[100]$} \\
\hline $\begin{array}{l}\text { Aqueous } \\
\text { extract }\end{array}$ & $\begin{array}{c}(180 \text { and } \\
360 \mathrm{mg} / \mathrm{ml})\end{array}$ & Rat arterial rings & Showed vasodilatation effect & {$[104]$} \\
\hline
\end{tabular}

with $F$. assa-foetida eliminates and improve the symptoms, including bloating (58\%), appetite $(69 \%)$, postprandial fullness (74\%), motion sickness (75\%), and indigestion (77\%) as compared to less than $10 \%$ improvement of symptoms in the placebo group [105]. The effects of F. assa- foetida mouthwash (10\%) twice daily for a period of 7 days compared to chlorhexidine gluconate $(\mathrm{CHG})$ mouthwash $(15 \mathrm{ml})$ were also studied. The result of the research was that modified gingival index (MGI) and the plaque index (PI) were improved in both groups of intervention. However, 
mean differences of MGI and PI in F. assa-foetida group were lower than the CHG group [106]. The effects of 50\% water-ethanol roots extracts of $F$. assa-foetida prepared as masculine tablet $(310 \mathrm{mg})$ on young men for 3 months were studied. Masculinity reduced production and release of MDA in human sperm cells. Furthermore, treatment with masculine tablet increased sperm motility and sperm count in 15 oligospermic volunteers (60\%) compared with the baseline of the study [104].

3.5. Nigella sativa L. Nigella sativa L. (N. sativa) or black seed is an annual plant that belongs to the Ranunculaceae family. It grows natively in Southwest Asia, Southern Europe, and North Africa and cultivates in different parts of the world [107]. N. sativa has been used in folk medicine for treatment of fever, infection, inflammation, chest congestion, cough, bronchitis, asthma, dysmenorrhea, diabetes, flatulence, dyspepsia, diarrhea, and dysentery [108, 109]. Pharmacological effects of $N$. sativa and its active constituent, thymoquinone (TQ), including anti-inflammatory, antioxidant, neuroprotective, and renoprotective effects has been reported [110-113]. N. sativa extract also showed the highest antibacterial and inhibitory activity against zucchini yellow mosaic virus (ZYMV) [114].

3.5.1. Anti-Inflammatory Effects of $N$. sativa. Culture medium of nonactivated peripheral blood mononuclear cell (PBMC) and allogeneic cells exposed to $N$. sativa extract (1 and $2 \mu \mathrm{g} / \mathrm{ml}$ ) stimulate production of IL- $1 \beta$ and IL-4 levels. Furthermore, N. sativa $(10 \mu \mathrm{g} / \mathrm{ml})$ suppresses the production of IL-8 in nonstimulated as well as mitogen-activated PBMC cells [115]. N. sativa aqueous extract $(50 \mu \mathrm{g} / \mathrm{ml})$ suppresses lymphocytes response to all mitogens and allogeneic cells. However, $N$. sativa $(0.5 \mu \mathrm{g} / \mathrm{ml})$ stimulates lymphocytes response to allogeneic cells. Moreover, the fraction of $N$. sativa $(10 \mathrm{kDa})$ stimulates the production of IL- $1 \beta$ and IL-3 by human lymphocytes without need for any kind of mitogen. N. sativa $(0.5 \mu \mathrm{g} / \mathrm{ml})$ also significantly increased IL-3 production when it was added to lymphocytes culture [116].

The preventive effects of $N$. sativa extract $(1.25$ and $2.50 \mathrm{~g} / \mathrm{L}$, p.o.) on guinea pigs OVA-induced asthma significantly decreased the levels of IL-4 and pathological changes, including intra-alveolar hemorrhage and inflammatory cells of the lung, but increased IFN- $\gamma$ [117]. In another experiment, the hydroethanolic extract of $N$. sativa $(0.08 \mathrm{~g}$ in drinking water) decreased neutrophil numbers and restored IL-4, and IFN- $\gamma$ levels in sulfur mustard $\left(40 \mathrm{mg} / \mathrm{m}^{3}\right)$ exposed animals $[117,118]$.

Intragastric gavage of $N$. sativa oil $(5 \mathrm{ml} / \mathrm{kg})$ showed anti-inflammatory effects on conalbumin-induced asthma in mice. Peripheral blood eosinophil count, IgG1 and IgG2a levels, and cytokines, including IL-2, IL-12, and IFN- $\gamma$ levels in lung tissue, were significantly decreased [119].

Administration of $N$. sativa oil ( $5 \mathrm{ml} / \mathrm{kg}$, intragastrically) in mice model of allergic asthma significantly reduced peripheral blood eosinophils and lung inflammation but did not reduce lung tissue induced nitric oxide synthase (iNOS) expression compared with the control group [120].
Treatment of OVA-sensitized mice with the main component of $N$. sativa, TQ (3 mg/kg, i.p.) for five days period definitely decreased sensitivity of the tracheal smooth muscle aroused by acetylcholine and histamine $71 \%$ and $74 \%$, respectively, compared to the sensitized animals. TQ $(8 \mathrm{mg} / \mathrm{kg}$, i.p.) prevented most of the pathological changes due to lipopolysaccharide- (LPS-) induced inflammatory cells infiltration, lipid peroxidation (LP), glutathione depletion (GSH), TNF- $\alpha$, and IL- $1 \beta$ levels in both BALF and lung tissue homogenates [121].

Intraperitoneal administration of TQ $(3 \mathrm{mg} / \mathrm{kg})$ before OVA-sensitized mice airway significantly decreased eosinophil count in the lung and also increased Th2 cytokines in the BAL fluid after airway challenge with OVA antigen. TQ also reduced the serum levels of immunoglobulin (Ig) E and IgG1. Additionally, TQ significantly inhibited eosinophilic lung inflammation and mucus-producing goblet cells in the histological assessment. TQ also significantly reduces the levels of IL-4, IL-5, and IL-13 in the BAL fluid [122].

Administration of TQ (20 and $40 \mathrm{mg} / \mathrm{kg}$, i.p.) and codeine $(5 \mathrm{mg} / \mathrm{kg})$, as a prototype antitussive agent, reduced the amount of cough in guinea pigs exposed to citric acid $20 \%$. The antitussive effect of TQ was antagonized by pretreatment with an opioid receptor antagonist (naloxone, $2 \mathrm{mg} / \mathrm{kg}$ ) [123].

The hydroethanolic extract of $N$. sativa ( $0.08 \mathrm{~g}$ daily) on sulfur mustard exposed guinea pigs caused the reduction of tracheal responsiveness to methacholine as well as total and differential WBC count in treated compared to untreated animals [124]. Similarly, N. sativa significantly decreased tracheal responsiveness and lung inflammation including the percentage of eosinophil and monocyte, neutrophil, and lymphocyte number in guinea pigs 14 days after sulfur mustard exposure [118].

Coadministration of $N$. sativa seeds ( $2 \mathrm{~g}$ ) with bee honey (1 teaspoon per day), for three month-duration, in asthmatics and nonasthmatics subjects (8 to 40 years) in Khartoum showed significantly improvement in forced vital capacity (FVC) in asthmatics' group and peak expiratory flow rate (PEFR) in nonasthmatics' group [125].

Administration of $N$. sativa capsules $(40-80 \mathrm{mg} / \mathrm{kg} /$ day, p.o.) in adults and children with allergic rhinitis, atopic eczema, and asthma significantly reduced plasma and urine levels of IgE, eosinophil count, and endogenous cortisol compared to their pretreatment values [126].

The effect of $N$. sativa ( 1 and $2 \mathrm{~g} /$ day for 6 - to 12 -week duration) supplementation decreased inflammation of the airways and also reversed limitation of airflow, including forced midexpiratory flow (FEF) 25-75\% and forced expiratory volume in 1 second (FEV1) \% in asthma patients. In addition, $N$. sativa (1 and $2 \mathrm{~g} /$ day) significantly improved PEF variability after 6 and 12 weeks of treatment compared to the controls group. The plant also decreased fractional exhaled nitric oxide (FeNO) and serum IgE after 12 weeks of treatment compared to the baseline. N. Sativa also increased serum IFN-gamma as well as improved in the asthma control test (ACT) score [127].

The finding from different studies indicated that $N$. sativa has some effects on serum immunoglobulin, antibody titer, eosinophil count, and cytokine profiles. 
TABLE 4: Anti-inflammatory and smooth muscle relaxant effects of $N$. sativa.

\begin{tabular}{|c|c|c|c|c|}
\hline Extract & Doses & Model of study & Effects & Reference \\
\hline Aqueous ethanolic & $\begin{array}{l}10 \mu \mathrm{g} / \mathrm{ml}, 1 \text { and } \\
2 \mu \mathrm{g} / \mathrm{ml}\end{array}$ & Culture medium of PBMC & $\begin{array}{l}\text { Increased IL-1 } \beta \text { and IL- } 4 \text { levels but suppressed the } \\
\text { production of IL- } 8\end{array}$ & {$[115]$} \\
\hline Aqueous & $50 \mu \mathrm{g} / \mathrm{ml}, 0.5 \mu \mathrm{g} / \mathrm{ml}$ & $\begin{array}{l}\text { Human lymphocytes } \\
\text { culture }\end{array}$ & $\begin{array}{l}\text { Suppressed lymphocytes response to all mitogens and } \\
\text { allogeneic cells, Stimulated lymphocytes response to } \\
\text { allogeneic cells, but stimulated the production of IL-1 } \beta \\
\text { and IL-3 and increased IL- } 3 \text { production }\end{array}$ & [116] \\
\hline Aqueous & $\begin{array}{l}1.25 \text { and } 2.50 \mathrm{~g} / \mathrm{L} \\
\text { p.o }\end{array}$ & $\begin{array}{l}\text { Guinea pigs model of } \\
\text { asthma }\end{array}$ & $\begin{array}{l}\text { Decreased the levels of IL- } 4 \text { and pathological changes, } \\
\text { while increased IFN- } \gamma\end{array}$ & [117] \\
\hline Aqueous & $\begin{array}{l}0.08 \mathrm{~g} \text { in drinking } \\
\text { water }\end{array}$ & $\begin{array}{l}\text { Sulfur mustard exposed } \\
\text { Guinea pigs }\end{array}$ & $\begin{array}{l}\text { Decreased neutrophil numbers and restored IL- } 4 \text { and } \\
\text { IFN- } \gamma \text { levels }\end{array}$ & {$[117,118]$} \\
\hline N. sativa oil & $5 \mathrm{ml} / \mathrm{kg}$ & Mice model of asthma & $\begin{array}{l}\text { Decreased Peripheral blood eosinophil count, IgG1 } \\
\text { and IgG2a levels, and cytokines including; IL-2, IL-12, } \\
\text { and IFN- } \gamma \text { levels in lung tissue }\end{array}$ & [119] \\
\hline N. sativa oil & $\begin{array}{l}5 \mathrm{ml} / \mathrm{kg} \\
\text { intragastrically }\end{array}$ & Mice model of asthma & $\begin{array}{c}\text { Reduced peripheral blood eosinophils and lung } \\
\text { inflammation }\end{array}$ & {$[120]$} \\
\hline $\begin{array}{l}\text { Main component, } \\
\text { TQ }\end{array}$ & $\begin{array}{l}3 \mathrm{mg} / \mathrm{kg}, 8 \mathrm{mg} / \mathrm{kg} \\
\text { i.p. }\end{array}$ & OVA sensitization mice & $\begin{array}{l}\text { Decreased sensitivity of the tracheal smooth muscle by } \\
\text { acetylcholine and histamine, cells infiltration, TNF- } \alpha \text {, } \\
\text { and IL- } 1 \beta \text { levels in both bronchoalveolar lavage fluid } \\
\text { (BALF) and lung tissue homogenates }\end{array}$ & [121] \\
\hline $\begin{array}{l}\text { Main component, } \\
\text { TQ }\end{array}$ & $3 \mathrm{mg} / \mathrm{kg}$, i.p. & OVA sensitization mice & $\begin{array}{l}\text { Decreased eosinophil count in the lung and increased } \\
\text { Th2 cytokines in the BAL fluid, reduced the elevated } \\
\text { serum levels of immunoglobulin (Ig)-E and IgG1, } \\
\text { inhibited lung eosinophilic inflammation and mucus- } \\
\text { producing goblet cells, inhibited the levels of IL-4, IL-5 } \\
\text { and IL-13 in the BAL fluid }\end{array}$ & {$[122]$} \\
\hline $\begin{array}{l}\text { Main component, } \\
\text { TQ }\end{array}$ & $\begin{array}{l}20 \text { and } 40 \mathrm{mg} / \mathrm{kg} \text {, } \\
\text { i.p. }\end{array}$ & Guinea pigs & Showed antitussive effect & {$[123]$} \\
\hline Hydroethanolic & $0.08 \mathrm{~g}$ daily & $\begin{array}{l}\text { Sulfur mustard exposed } \\
\text { guinea pigs }\end{array}$ & $\begin{array}{l}\text { Reduced tracheal responsiveness to methacholine and } \\
\text { also decreased total and differential WBC count }\end{array}$ & {$[124]$} \\
\hline Hydroethanolic & $0.08 \mathrm{~g}$ daily & $\begin{array}{l}\text { Sulfur mustard exposed } \\
\text { guinea pigs }\end{array}$ & $\begin{array}{l}\text { Decreased tracheal responsiveness and lung } \\
\text { inflammation including, percentage of eosinophil and } \\
\text { monocyte, neutrophil, and lymphocyte number }\end{array}$ & {$[118]$} \\
\hline N. sativa seeds & $2 \mathrm{~g}$ & $\begin{array}{l}\text { Asthmatics and } \\
\text { nonasthmatics subjects }\end{array}$ & $\begin{array}{c}\text { Increased FVC in asthmatics' group and PEFR in } \\
\text { nonasthmatics' group }\end{array}$ & {$[125]$} \\
\hline Capsules & $\begin{array}{l}40-80 \mathrm{mg} / \mathrm{kg} / \text { day, } \\
\text { p.o. }\end{array}$ & $\begin{array}{l}\text { Rhinitis, atopic eczema } \\
\text { and asthma }\end{array}$ & $\begin{array}{l}\text { Reduced plasma and urine levels of IgE, eosinophil } \\
\text { count, and endogenous cortisol }\end{array}$ & {$[126]$} \\
\hline Supplement & 1 and $2 \mathrm{~g} /$ day & Asthma patients & $\begin{array}{l}\text { Increased PFT values, including FEF } 25-75 \% \text { and FEV1 } \\
\% \text {, improved PEF, decreased FeNO and serum IgE, and } \\
\text { increased serum IFN-gamma }\end{array}$ & [127] \\
\hline N. sativa seeds & $0.1-3.0 \mathrm{mg} / \mathrm{ml}$ & $\begin{array}{l}\text { Rabbit jejunum, guinea pig } \\
\text { trachea smooth muscle }\end{array}$ & $\begin{array}{l}\text { Induced relaxant effects on carbachol-, histamine- or } \\
\mathrm{K}(+) \text {-induced contractions in guinea-pig trachea } \\
\text { smooth muscle trough calcium channel blocking } \\
\text { effects }\end{array}$ & {$[128]$} \\
\hline Aqueous extract & $0.25,0.5$ and $1 \mathrm{~g} \%$ & $\begin{array}{l}\text { Guinea pig tracheal } \\
\text { smooth muscle }\end{array}$ & Showed calcium antagonist effects & [129] \\
\hline Aqueous extract & $0.25,0.5$ and $1 \mathrm{~g} \%$ & $\begin{array}{l}\text { Guinea pigs isolated } \\
\text { trachea chain }\end{array}$ & $\begin{array}{l}\text { Showed relaxant effect by stimulatory effect on } \beta 2 \text { - } \\
\text { adrenoceptors }\end{array}$ & {$[130]$} \\
\hline Aqueous extract & $\begin{array}{l}0.8,1.2,1.6 \text { and } \\
2.0 \mathrm{~g} \%\end{array}$ & Guinea pig tracheal chains & Showed significant relaxant effects & [131] \\
\hline $\begin{array}{l}\text { Hydroethanolic } \\
\text { extract }\end{array}$ & $\begin{array}{l}0.125 \text { and } 0.250 \mathrm{mg} / \\
\mathrm{ml}\end{array}$ & Guinea pig tracheal chains & $\begin{array}{l}\text { Decreased tracheal response to methacholine and } \\
\text { ovalbumin, improved WBC cell and eosinophil counts } \\
\text { in the lung lavage fluid }\end{array}$ & {$[132]$} \\
\hline $\begin{array}{l}\text { Methanolic } \\
\text { fractions }\end{array}$ & $\begin{array}{l}20 \%, 40 \%, 60 \% \\
80 \% \text {, and } 100 \%\end{array}$ & Guinea pig tracheal chains & Showed significant relaxant effects & [133] \\
\hline Aqueous extract & $2-14 \mathrm{mg} / \mathrm{mL}$ & $\begin{array}{l}\text { Contractile responses of rat } \\
\text { isolated aorta }\end{array}$ & Showed vasodilator effect & {$[134]$} \\
\hline Boiled extract & 50 and $100 \mathrm{mg} / \mathrm{kg}$ & Asthmatic patients & $\begin{array}{l}\text { Increased all measured PFTs values, bronchodilatory } \\
\text { effect }\end{array}$ & {$[135]$} \\
\hline
\end{tabular}

IL: interleukin; IFN- $\gamma$ : interferon-gamma; TNF- $\alpha$ : tumor necrosis factor- $\alpha$; NO: nitrogen oxide; Ig: immunoglobulin; BAL: bronchoalveolar lavage; PEFR: peak expiratory flow rate; PFT: pulmonary function tests; FVC: forced vital capacity. 


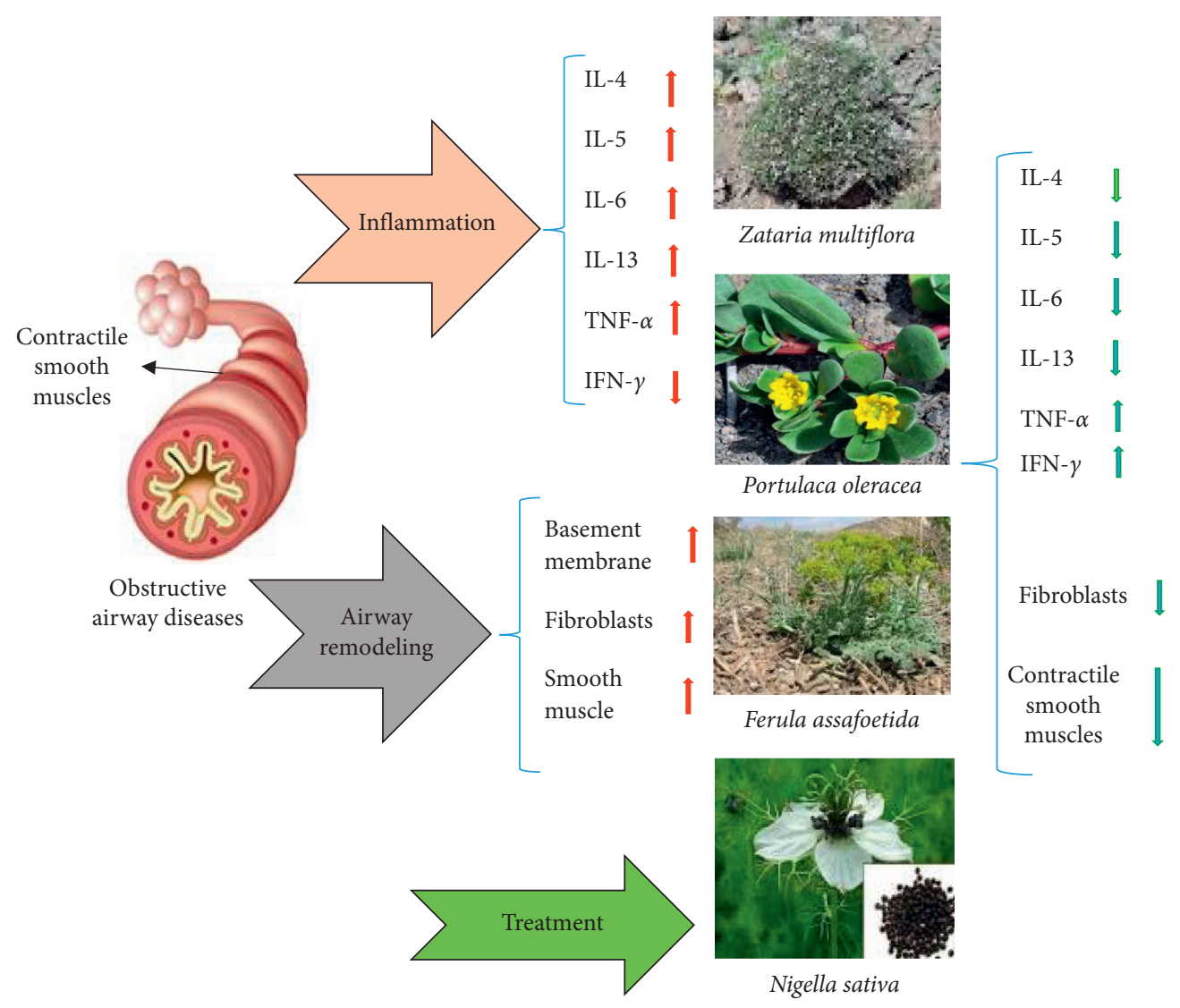

FIgURE 1: The possible therapeutic actions of the plants on the respiratory system.

3.5.2. Relaxant Effect on Tracheal Smooth Muscle. The crude extract of $N$. sativa seeds $(0.1-3.0 \mathrm{mg} / \mathrm{ml})$ exhibited contraction effect on rabbit jejunum. The extract of the plant creates a dose-dependent shift to the right in the $\mathrm{Ca}^{2+}$ doseresponse curves similar to verapamil and exhibits a calcium channel blocker effect. $N$. sativa extract $(0.1-3.0 \mathrm{mg} / \mathrm{ml})$ also has a relaxant effect on carbachol, histamine, or $\mathrm{K}(+)$ induced contractions in guinea pig trachea smooth muscle trough calcium channel blocking effects [128]. The aqueous extract of $N$. sativa $(0.25,0.5$, and $1 \mathrm{~g} \%)$ creates the rightward shift in calcium concentration-response curves of calcium-induced contraction of guinea pig tracheal smooth muscle, which may be due to calcium antagonist effects of the extract [129].

The relaxant effect of the aqueous extract of $N$. sativa $(0.25,0.5$, and $1 \mathrm{~g} \%)$ on the guinea pig's isolated trachea chain was also examined. The extract of $N$. sativa compared with saline showed a dose-dependent stimulatory effect on $\beta 2$-adrenoceptors and eventually led to tracheal smooth muscles relaxation [130]. The aqueous fractions of $N$. sativa $(0.8,1.2,1.6$, and $2.0 \mathrm{~g} \%)$ showed significant relaxant effects on precontracted guinea pig tracheal chains by $\mathrm{KCl}(60 \mathrm{mM})$ and methacholine $(10 \mu \mathrm{M})$ [131].

The hydroethanolic extract of $N$. sativa (0.125 and $0.250 \mathrm{mg} / \mathrm{ml}$ ) significantly decreased tracheal response of isolated trachea chain to methacholine and ovalbumin compared to the controls. Moreover, the extract significantly decreased WBC cell and eosinophil counts in the lung lavage fluid [132].
In another study, the relaxant effects of methanolic fractions $(20 \%, 40 \%, 60 \%, 80 \%$, and $100 \%)$ of $N$. sativa on precontracted tracheal smooth muscle of guinea pig by $\mathrm{KCl}$ and methacholine demonstrated significant relaxant effects to the extent that $20 \%$ methanolic fraction had higher relaxant effect than theophylline [133].

The vasodilator effect of $N$. sativa extract $(2-14 \mathrm{mg} / \mathrm{mL})$ on $\mathrm{KCl}$ induced contractile responses of the isolated aorta and also on endothelium-intact and endothelium-denuded aortic rings precontracted by phenylephrine and $\mathrm{KCl}$ has seen [134]. The bronchodilatory effects of $N$. sativa boiled extract (50 and $100 \mathrm{mg} / \mathrm{kg}$ ) compared to theophylline $(6 \mathrm{mg} /$ $\mathrm{kg})$ in asthmatic patients $(n=15)$ become obvious in improvement of all measured PFTs values, in most time intervals. However, the increase in PFT values was significantly lower than those of theophylline, whereas the onset of the bronchodilatory effect of the extract was similar to that of theophylline beginning $30 \mathrm{~min}$ after administration [135].

The results of these studies indicated that $N$. sativa could be applied for the treatment of inflammatory disorders, including allergy and asthma. Noteworthy, anti-inflammatory effects of the plant indicated that these plants and their main components might be useful for treatments of respiratory disorders such as cold and improves some measures of pulmonary function and subsides respiratory symptoms such as cough in children and adults. The anti-inflammatory and smooth muscle relaxant effects of $N$. sativa are shown in Table 4. 
3.5.3. Clinical Evidences. Treatment of rheumatoid arthritis (RA) patients with two capsules of Nigella sativa oil $(500 \mathrm{mg}$, per day for 8 weeks) significantly increased IL-10 serum level, whereas it decreased serum levels of MDA and nitric oxide compared with the placebo group [136].

Whole ground seeds of $N$. sativa ( 1 and $2 \mathrm{~g} /$ day, capsules) significantly decreased fractional exhaled nitric oxide (FeNO) and serum immunoglobulin $\mathrm{E}(\mathrm{IgE})$ in asthmatic patients after 12 weeks compared to the baseline. Serum levels of IFN- $\gamma$ were significantly increased after 12 weeks of treatment with $N$. sativa compared to the baseline [127]. Treatment with soft gel capsules of $N$. sativa oil $(15-30 \mathrm{mg} / \mathrm{kg} /$ day) significantly increased serum levels of IFN- $\gamma$ and reduced serum levels of IL-4 in asthmatic children (aged 6-15) compared to control [137]. In one study, researchers showed that the oils of $N$. sativa $(15-30 \mathrm{mg} / \mathrm{kg})$ significantly decreased Th17 and also increased Treg percentages. In the same way, Th17/Treg ratio was lower in N. sativa treated group compared to the standard treated group [138]. Supplementation with $N$. sativa oil in patients with nonalcoholic fatty liver disease (NAFLD) for 8 weeks decreased the level of FBS, lipid profiles (TG, TC, LDL, and VLDL), liver enzymes (AST and ALT), inflammatory marker (hsCRP, IL-6, and TNF- $\alpha$ ), whereas it increased the HDL-C levels compared to the placebo (paraffin oil) group [139]. $N$. sativa supplementation ( $2 \mathrm{~g} /$ day for 12 weeks) in patients who have cardiovascular disorders risk factors and also in patients with NAFLD 2 significantly decreased glucose and insulin serum levels and also decreased hepatic steatosis percentage compared to the placebo [140].

Potential therapeutic effects of the medicinal plants on respiratory system, including anti-inflammatory and relaxant effects on tracheal smooth muscle, are shown in Figure 1.

\section{Conclusion}

This review highlighted the anti-inflammatory and smooth muscle relaxant effects of various medicinal plants that have been used frequently for dietary, food additive, and spice among the people of different countries. They have anti-inflammatory properties, including reduction in inflammatory cytokine, total white blood cells, neutrophils, and eosinophils in the blood and BAL fluid in induced asthma or COPD of animal's model. Furthermore, these plants attenuated tracheal responsiveness and smooth muscle contraction via inhibition of histamine and muscarinic receptors or via agonistic effects on $\beta$ adrenergic receptors. Therefore, according to the basic and clinical evidence, these plants have potential of therapeutic effects on allergic asthma and obstructive airway disorders. So, because of safety and easy use, these medicinal plants and their main components can be suggested for treatments of acute cough in patients with cold and also for relief of chronic cough in patients with chronic respiratory disorders such as COPD and especially in childhood asthma.

\section{Abbreviations}

Ach: Acetylcholine

ACT: Asthma control test

BAL: Bronchoalveolar lavage

COPD: Chronic obstructive pulmonary disease

DCs: Dendritic cells

ET: Endothelin

FEF: Forced expiratory flow

FEV1: Forced expiratory volume in 1 second

FOXP3: Forkhead box P3

FVC: $\quad$ Forced vital capacity

IBD: Inflammatory bowel diseases

ICAM: Intracellular cell adhesion molecular

IFN $\gamma$ : Interferon-gamma

IgE: Immunoglobulin $\mathrm{E}$

IL: Interleukin

iNOS: Induced nitric oxide synthase

MAO-B: Monoamine oxidase B

MCP-1: Chemoattractant protein 1

MMP-2: Mediated matrix metalloproteinase 2

NO: $\quad$ Nitric oxide

OVA: Ovalbumin

PBMC: Peripheral blood mononuclear cells

PEFR: Peak expiratory flow rate

PFT: Pulmonary function tests

PLA2: Phospholipase A2

POP: Polysaccharide

ROS: $\quad$ Reactive oxygen species

SI: $\quad$ Stimulation indices

SM: $\quad$ Sulfur mustard

SNP: $\quad$ Sodium nitroprusside

Th: T-helper

TLR-4: Toll-like receptor 4

TNF $\alpha$ : Tumor necrosis factor- $\alpha$

TQ: Thymoquinone

VCAM: Vascular cell adhesion molecule

WBC: White blood cells

WHO: World Health Organization

\section{Data Availability}

No data were used to support this study.

\section{Conflicts of Interest}

The authors declare that there are no conflicts of interest regarding the publication of this paper.

\section{Authors' Contributions}

S. Gholamreza Mortazavi Moghaddam was responsible for donations to the study design, critical review, and editing of the manuscript. Majid Kianmehr helped in study design, search in literature, and the preparation of the manuscript. Mohammad Reza Khazdair made substantial contributions to the study design, search in literature, and development of the manuscript. All the authors approved the final version of the manuscript. 


\section{Acknowledgments}

The authors thank the Research Council of the Birjand University of Medical Sciences.

\section{References}

[1] M. Roxas and J. Jurenka, "Colds and influenza: a review of diagnosis and conventional, botanical, and nutritional considerations," Alternative Medicine Review: A Journal of Clinical Therapeutic, vol. 12, no. 1, p. 25, 2007.

[2] N. Ács, F. Bánhidy, E. Horváth-Puhó, and A. E. Czeizel, "Population-based case-control study of the common cold during pregnancy and congenital abnormalities," European Journal of Epidemiology, vol. 21, no. 1, pp. 65-75, 2006.

[3] A. B. Chang, L. I. Landau, P. P. Van Asperen et al., "Cough in children: definitions and clinical evaluation," Medical Journal of Australia, vol. 184, no. 8, pp. 398-403, 2006.

[4] A. B. Chang, "Cough: are children really different to adults?" Cough, vol. 1, no. 1, p. 7, 2005.

[5] F. Thomson, I. Masters, and A. Chang, "Persistent cough in children and the overuse of medications," Journal of Paediatrics and Child Health, vol. 38, no. 6, pp. 578-581, 2002.

[6] B. G. o. t. M. o. Asthma, British Thoracic Society and Scottish Intercollegiate Guidelines Network, 2012.

[7] R. D. Sewell and M. Rafieian-Kopaei, "The history and ups and downs of herbal medicines usage," Journal of HerbMed Pharmacology, vol. 3, 2014.

[8] A. Sarrafchi and M. Rafieian-Kopaei, "The role of community in discovery of new drugs from herbal medicines," Journal of HerbMed Pharmacology, vol. 3, 2014.

[9] A. Ghorbani, M. Rafieian-Kopaie, and H. Nasri, "Lipoprotein (a): more than a bystander in the etiology of hypertension? A study on essential hypertensive patients not yet on treatment," Journal of Nephropathology, vol. 2, no. 1, p. 67, 2013.

[10] H. Roohafza, N. Sarrafzadegan, M. Sadeghi, M. RafieianKopaei, F. Sajjadi, and H. Khosravi-Boroujeni, "The association between stress levels and food consumption among Iranian population," Archives of Iranian Medicine, vol. 16, no. 3, pp. 145-148, 2013.

[11] Avicenna, The Canon of Medicine, Persian Edition by Sharaf-Kandi, A.R. Book II, 1985.

[12] G. R. Amin, Popular Medicinal Plants of Iran, Iranian Research Institute of Medicinal Plants Tehran, Tehran, Iran, 1991.

[13] J. Li, X.-1. Wu, Y. Chen et al., “Antidiarrheal properties of different extracts of Chinese herbal medicine formula BaoXie-Ning," Journal of Integrative Medicine, vol. 11, no. 2, pp. 125-134, 2013.

[14] C.-q. Zhao, Y. Zhou, J. Ping, and L.-m. Xu, "Traditional Chinese medicine for treatment of liver diseases: progress, challenges and opportunities," Journal of Integrative Medicine, vol. 12, no. 5, pp. 401-408, 2014.

[15] M. Razi, "Al-Hawi fi'l-tibb (comprehensive book of medicine)," Osmania Oriental Publications Bureau, vol. 20, pp. 548-553, 1968.

[16] I. A. Ross, "Medicinal plants of the world," Chemical Constituents, Traditional and Modern Medicinal Uses, Vol. 3, Springer Science \& Business Media, Berlin, Germany, 2007.

[17] A. Y. Leung, Encyclopedia of Common Natural Ingredients Used in Food, Drugs, and Cosmetics, Wiley, Hoboken, NJ, USA, 1980.
[18] A. Gilani, N. Aziz, I. Khurram et al., "Bronchodilator, spasmolytic and calcium antagonist activities of Nigella sativa seeds (Kalonji): a traditional herbal product with multiple medicinal uses," Journal of Pakistan Medical Association, vol. 51, no. 3, p. 115, 2001.

[19] S. Y. Kim, Y.-J. Chang, H. M. Cho, Y.-W. Hwang, and Y. S. Moon, "Non-steroidal anti-inflammatory drugs for the common cold," Cochrane Database of Systematic Reviews, vol. 6, 2013.

[20] R. B. D’agostino, M. Weintraub, H. K. Russell et al., "The effectiveness of antihistamines in reducing the severity of runny nose and sneezing: a meta-analysis," Clinical Pharmacology \& Therapeutics, vol. 64, no. 6, pp. 579-596, 1998.

[21] A. I. De Sutter, M. L. van Driel, A. A. Kumar et al., "Oral antihistamine-decongestant-analgesic combinations for the common cold," Cochrane Database of Systematic Reviews, vol. 2, 2012.

[22] M. Simasek and D. A. Blandino, "Treatment of the common cold," American Family Physician, vol. 75, no. 4, 2007.

[23] M. A. McKinlay, D. C. Pevear, and M. G. Rossmann, "Treatment of the picorna virus common cold by inhibitors of viral uncoating and attachment," Annual Review of Microbiology, vol. 46, no. 1, pp. 635-656, 1992.

[24] W. Al-Nakib, P. G. Higgins, G. I. Barrow et al., "Suppression of colds in human volunteers challenged with rhinovirus by a new synthetic drug (R61837)," Antimicrobial Agents and Chemotherapy, vol. 33, no. 4, pp. 522-525, 1989.

[25] F. G. Hayden, G. J. Hipskind, D. H. Woerner et al., "Intranasal pirodavir $(\mathrm{R} 77,975)$ treatment of rhinovirus colds," Antimicrobial Agents and Chemotherapy, vol. 39, no. 2, pp. 290-294, 1995.

[26] S. L. Spector and R. Nicklas, "Practice parameters for the diagnosis and treatment of asthma," Journal of Allergy and Clinical Immunology, vol. 96, 1995.

[27] G. J. Rodrigo and J. A. Castro-Rodríguez, "Safety of longacting $\beta$ agonists for the treatment of asthma: clearing the air," Thorax, vol. 67, no. 4, pp. 342-349, 2012.

[28] Z. Gholamnezhad, M. H. Boskabady, M. R. Khazdair, M. Hosseini, and M. Abbasnejad, "Effect of fluticasone and salmeterol on tracheal responsiveness to ovalbumin and lung inflammation, administrated during and after sensitization," The Scientific World Journal, vol. 2014, Article ID 865292, 8 pages, 2014.

[29] M. Boskabady, A. Tabatabaee, M. Hosseini, M. Abbasnejad, and M. Khazdair, "Effect of inhaled fluticasone and salmeterol on tracheal responsiveness and lung inflammation: influence of administration time and allergen-free period," Indian Journal of Medical Sciences, vol. 67, no. 3, pp. 78-88, 2013.

[30] W. B. Jonas, "Dictionary of complementary and alternative medicine," The Journal of Alternative and Complementary Medicine, vol. 11, no. 4, pp. 739-740, 2005.

[31] T. Efferth and E. Koch, "Complex interactions between phytochemicals. The multi-target therapeutic concept of phytotherapy," Current Drug Targets, vol. 12, no. 1, pp. 122-132, 2011.

[32] M. M. Cowan, "Plant products as antimicrobial agents," Clinical Microbiology Reviews, vol. 12, no. 4, pp. 564-582, 1999.

[33] P. A. Clarke, "Aboriginal uses of plants as medicines, narcotics, and poisons in Southern South Australia," 1987.

[34] A. Zargari, Herbal Medicines, Vol. 83, Publication of Tehran University, Tehran, Iran, 1990. 
[35] IH Pharmacopoeia, Ministry of Health and Medical Publications, Tehran, Iran, 2002.

[36] M. R. Khazdair, A. Anaeigoudari, M. Hashemzehi, and R. Mohebbati, "Neuroprotective potency of some spice herbs, a literature review," Journal of Traditional and Complementary Medicine, vol. 9, no. 2, pp. 98-105, 2019.

[37] M. R. Khazdair, V. Ghorani, A. Alavinezhad, and M. H. Boskabady, "Pharmacological effects of Zataria multiflora Boiss L. and its constituents focus on their antiinflammatory, antioxidant, and immunomodulatory effects," Fundamental \& Clinical Pharmacology, vol. 32, no. 1, pp. 26-50, 2018.

[38] F. Naghibi, M. Mosaddegh, M. Mohammadi Motamed et al., "Labiatae family in folk medicine in Iran: from ethnobotany to pharmacology," Iranian Journal of Pharmaceutical Research, vol. 4, no. 2, pp. 63-79, 2010.

[39] K. Zomorodian, M. Saharkhiz, M. Rahimi et al., "Chemical composition and antimicrobial activities of the essential oils from three ecotypes of Zataria multiflora," Pharmacognosy Magazine, vol. 7, no. 25, p. 53, 2011.

[40] V. Mozaffarian, A Dictionary of Iranian Plant Names: Latin, English, Persian, Farhang Mo'aser, Tehran, Iran, 1996.

[41] M. H. Boskabady and L. Gholami Mhtaj, "Effect of the Zataria multiflora on systemic inflammation of experimental animals model of COPD," BioMed Research International, vol. 2014, Article ID 802189, 9 pages, 2014.

[42] L. Gholami Mahtaj, M. Boskabady, and N. Mohamadian Roshan, "The effect of Zataria multiflora and its constituent, carvacrol, on tracheal responsiveness and lung pathology in Guinea pig model of COPD," Phytotherapy Research, vol. 29, no. 5, pp. 730-736, 2015.

[43] M. H. Boskabady, S. Jalali, T. Farkhondeh, and G. Byrami, "The extract of Zataria multiflora affect tracheal responsiveness, serum levels of NO, nitrite, PLA2, TP and histamine in sensitized Guinea pigs," Journal of Ethnopharmacology, vol. 156, pp. 301-308, 2014.

[44] H. Hosseinzadeh, M. Ramezani, and G.-a. Salmani, "Antinociceptive, anti-inflammatory and acute toxicity effects of Zataria multiflora Boiss extracts in mice and rats," Journal of Ethnopharmacology, vol. 73, no. 3, pp. 379-385, 2000.

[45] F. Jaffary, A. Ghannadi, and A. Siahpoush, "Antinociceptive effects of hydroalcoholic extract and essential oil of Zataria multiflora," Fitoterapia, vol. 75, no. 2, pp. 217-220, 2004.

[46] L. A. Nakhai, A. Mohammadirad, N. Yasa et al., "Benefits of Zataria multiflora boissin experimental model of mouse inflammatory bowel disease," Evidence-Based Complementary and Alternative Medicine, vol. 4, no. 1, pp. 43-50, 2007.

[47] G. Kavoosi, J. A. Teixeira da Silva, and M. J. Saharkhiz, "Inhibitory effects of Zataria multiflora essential oil and its main components on nitric oxide and hydrogen peroxide production in lipopolysaccharide-stimulated macrophages," Journal of Pharmacy and Pharmacology, vol. 64, no. 10, pp. 1491-1500, 2012.

[48] B. Mostafavi and S. Shasavari, "The effect of Zataria on respiratory disorders of chemical war victims," Behbood Journal, vol. 7, pp. 293-297, 2005.

[49] H. Afzali, M. Darabi, and M. Kashanian, "The effect of Zataria multiflora and Foeniculum vulgare in acute cough," in Proceedings of the 16th Iranian Congresss of Physiology and Pharmacology, Tehran, Iran, May 2003.

[50] M. H. Boskabady, Z. Jafari, I. Pouraboli, B. Babazade, and M. G. Rahbardar, "Anti-cholinergic effect of Zataria multiflora Boiss on Guinea pig tracheal chains," Natural Product Research, vol. 26, no. 16, pp. 1523-1528, 2012.
[51] M. H. Boskabady and H. Tabanfar, "Effect of Zataria Multiflora Bois L. on histamine (H1) Receptor of guinea pig tracheal chains," 2011.

[52] M. H. Boskabady, H. Tabanfar, Z. Gholamnezhad, and H. R. Sadeghnia, "Inhibitory effect of Zataria multiflora Boiss and carvacrol on histamine (H1) receptors of Guinea-pig tracheal chains," Fundamental \& Clinical Pharmacology, vol. 26, no. 5, pp. 609-620, 2012.

[53] M. K. M. H. Boskabady, N. Eftekhar, and A. Nemati, "The effect of Zataria multiflora boiss on $\beta 2$-adrenoceptors of Guinea pig tracheal cahins," Pharmacologyonline, vol. 1, pp. 749-756, 2009.

[54] M. Gharib Naseri, H. Mazlomi, M. Goshaiesh et al., "Antispasmodic effect of Zataria multiflora Boiss. leaf extract on the rat uterus," Iranian Journal of Pharmaceutical Research, vol. 5, no. 2, pp. 131-136, 2010.

[55] M. K. G. Naseri, "Effect of Zataria multiflora Boiss leaf hydroalcoholic extract on rat ileum," Journal of Kermanshah University of Medical Sciences, vol. 7, no. 3, 2003.

[56] Y. Aydin, Ö. Kutlay, S. Ari, S. Duman, K. Uzuner, and S. Aydin, "Hypotensive effects of carvacrol on the blood pressure of normotensive rats," Planta Medica, vol. 73, no. 13, pp. 1365-1371, 2007.

[57] M. R. Khazdair, O. Rajabi, M. Balali-Mood, F. Beheshti, and M. H. Boskabady, "The effect of Zataria multiflora on pulmonary function tests, hematological and oxidant/antioxidant parameters in sulfur mustard exposed veterans, a randomized doubled-blind clinical trial," Environmental Toxicology and Pharmacology, vol. 58, pp. 180-188, 2018.

[58] M. R. Khazdair, A. Alavinezhad, and M. H. Boskabady, "Carvacrol ameliorates haematological parameters, oxidant/ antioxidant biomarkers and pulmonary function tests in patients with sulphur mustard-induced lung disorders: a randomized double-blind clinical trial," Journal of Clinical Pharmacy and Therapeutics, vol. 43, no. 5, pp. 664-674, 2018.

[59] A. Alavinezhad, M. Hedayati, and M. H. Boskabady, "The effect of Zataria multiflora and carvacrol on wheezing, FEV1 and plasma levels of nitrite in asthmatic patients," Avicenna Journal of Phytomedicine, vol. 7, no. 6, p. 531, 2017.

[60] M. R. Khazdair, V. Ghorani, A. Alavinezhad, and M. H. Boskabady, "Effect of Zataria multiflora on serum cytokine levels and pulmonary function tests in sulfur mustard-induced lung disorders: a randomized double-blind clinical trial," Journal of Ethnopharmacology, vol. 248, Article ID 112325, 2020.

[61] M. R. Khazdair, F. Rezaeetalab, H. Rafatpanah et al., "The effect of Zataria multiflora on inflammatory cytokine and respiratory symptoms in veterans exposed to sulfur mustard," Environmental Science and Pollution Research, vol. 27, pp. 22451-22460, 2020.

[62] A. Alavinezhad, V. Ghorani, O. Rajabi, and M. H. Boskabady, "Zataria multiflora affects clinical symptoms, oxidative stress and cytokines in asthmatic patient: a randomized, double blind, placebo-controlled, phase II clinical trial," Cytokine, vol. 133, p. 155169, 2020.

[63] A. Zargari, Medicinal Plants, Tehrari University Publications, Tehran, Iran, 1995.

[64] A. P. Simopoulos, "Omega-3 fatty acids and antioxidants in edible wild plants," Biological Research, vol. 37, no. 2, pp. 263-277, 2004.

[65] M. T. Boroushaki, M. H. Boskabady, and F. Malek, "Antitussive effect of Portulaca oleracea L. in Guinea pigs," Iranian Journal of Pharmaceutical Research, vol. 3, no. 3, pp. 187-190, 2010. 
[66] K. Chan, M. W. Islam, M. Kamil et al., "The analgesic and anti-inflammatory effects of Portulaca oleracea L. subsp. sativa (Haw.) Celak," Journal of Ethnopharmacology, vol. 73, no. 3, pp. 445-451, 2000.

[67] R. Londonkar and H. B. Nayaka, "Phytochemical and antimicrobial activities of Portulaca oleracea L," Journal of Pharmacy Research, vol. 4, no. 10, pp. 3553-3555, 2011.

[68] V. R. Askari, S. A. Rezaee, K. Abnous et al., "The influence of hydro-ethanolic extract of Portulaca oleracea L. on Th $1 /$ Th 2 balance in isolated human lymphocytes," Journal of Ethnopharmacology, vol. 194, pp. 1112-1121, 2016.

[69] A. S. Lee, J. S. Kim, Y. J. Lee, D. G. Kang, and H. S. Lee, “AntiTNF- $\alpha$ activity of Portulaca oleracea in vascular endothelial cells," International Journal of Molecular Sciences, vol. 13, no. 5, pp. 5628-5644, 2012.

[70] S.-W. Seo, "The anti-inflammatory effect of Portulaca oleracea $70 \% \mathrm{EtOH}$ extracts on lipopolysaccharide-induced inflammatory response in RAW 264.7 cells," The Korea Journal of Herbology, vol. 30, no. 6, pp. 33-38, 2015.

[71] R. Zhao, T. Zhang, H. Zhao, and Y. Cai, "Effects of Portulaca oleracea L.polysaccharides on phenotypic and functional maturation of murine bone marrow derived dendritic cells," Nutrition and Cancer, vol. 67, no. 6, pp. 987-993, 2015.

[72] C. YouGuo, S. ZongJi, and C. XiaoPing, "Evaluation of free radicals scavenging and immunity-modulatory activities of Purslane polysaccharides," International Journal of Biological Macromolecules, vol. 45, no. 5, pp. 448-452, 2009.

[73] L.-s. Ke, J.-z. Guo, J.-y. Yang et al., “The immunomodulatory effect of the polysaccharides of Portulaca Oleracea on senescence mice," Heilongjiang Medicine and Pharmacy, vol. 2, p. 14, 2012.

[74] V. Baradaran Rahimi, H. Rakhshandeh, F. Raucci et al., "Anti-inflammatory and anti-oxidant activity of Portulaca oleracea extract on LPS-induced rat lung injury," Molecules, vol. 24, no. 1, p. 139, 2019.

[75] F. Okwuasaba, C. Ejike, and O. Parry, "Comparison of the skeletal muscle relaxant properties of Portulaca oleracea extracts with dantrolene sodium and methoxyverapamil," Journal of Ethnopharmacology, vol. 20, no. 2, pp. 85-106, 1987.

[76] F. Malek, M. H. Boskabady, M. T. Borushaki, and M. Tohidi, "Bronchodilatory effect of Portulaca oleracea in airways of asthmatic patients," Journal of Ethnopharmacology, vol. 93, no. 1, pp. 57-62, 2004.

[77] M. H. Boskabady, M. Hashemzehi, M. R. Khazdair et al., "Hydro-ethanolic extract of Portulaca oleracea affects betaadrenoceptors of Guinea pig tracheal smooth muscle," Iranian Journal of Pharmaceutical Research, vol. 15, no. 4, pp. 867-874, 2016.

[78] M. Hashemzehi, M. Khazdair, M. Kiyanmehr et al., "Portulaca olerace affects muscarinic receptors of Guinea pig tracheal smooth muscle," Indian Journal of Pharmaceutical Sciences, vol. 78, no. 3, pp. 388-394, 2016.

[79] C. A. E. Martin, E. Naline, H. Bakdach, and C. Advenier, "Beta 3-adrenoceptor agonists, BRL 37344 and SR 58611A, do not induce relaxation of human, sheep and Guinea-pig airway smooth muscle in vitro," European Respiratory Journal, vol. 7, no. 9, pp. 1610-1615, 1994.

[80] D. Buckle, J. Arch, N. Bowring et al., "Relaxant effects of the potassium channel activators BRL 38227 and pinacidil on Guinea-pig and human airway smooth muscle, and blockade of their effects by glibenclamide and BRL 31660," Pulmonary Pharmacology, vol. 6, no. 1, pp. 77-86, 1993.
[81] R. G. Van Amsterdam, H. Meurs, F. Brouwer et al., "Role of phosphoinositide metabolism in functional antagonism of airway smooth muscle contraction by $\beta$-adrenoceptor agonists," European Journal of Pharmacology: Molecular Pharmacology, vol. 172, no. 2, pp. 175-183, 1989.

[82] Y. Miyahara, Y. Kizawa, M. Sano et al., "Effects of organic and inorganic $\mathrm{Ca}(2+)$-antagonists on acetylcholine-induced contraction in molluscan (Mytilus edulis) smooth muscle," General Pharmacology, vol. 24, no. 6, pp. 1419-1423, 1993.

[83] E. S. Catap, M. J. L. Kho, and M. R. R. Jimenez, "In vivo nonspecific immunomodulatory and antispasmodic effects of common purslane (Portulaca oleracea Linn.) leaf extracts in ICR mice," Journal of Ethnopharmacology, vol. 215, pp. 191-198, 2018.

[84] A. S. Lee, Y. J. Lee, S. M. Lee et al., "Portulaca oleracea ameliorates diabetic vascular inflammation and endothelial dysfunction in $\mathrm{db} / \mathrm{db}$ mice," Evidence-Based Complementary and Alternative Medicine, vol. 2012, Article ID 741824, 9 pages, 2012.

[85] F. Oluwol and K. Oyediji, "Calcium ions influences smooth muscle relaxant response to aqueous extract of Portulaca oleracea," Journal of Medical Sciences, vol. 7, no. 2, pp. 238-242, 2007.

[86] O. Parry, F. Okwuasaba, and C. Ejike, "Effect of an aqueous extract of Portulaca oleracea leaves on smooth muscle and rat blood pressure," Journal of Ethnopharmacology, vol. 22, no. 1, pp. 33-44, 1988.

[87] M.-I. K. El-Sayed, "Effects of Portulaca oleracea L. seeds in treatment of type- 2 diabetes mellitus patients as adjunctive and alternative therapy," Journal of Ethnopharmacology, vol. 137, no. 1, pp. 643-651, 2011.

[88] O. Parry, F. Okwuasaba, and C. Ejike, "Preliminary clinical investigation into the muscle relaxant actions of an aqueous extract of Portulaca oleracea applied topically," Journal of Ethnopharmacology, vol. 21, no. 1, pp. 99-106, 1987.

[89] P. Farzanegi, "Impact of the synchronization of Portulaca oleracea and aerobic training on levels of MMP2 and MMP9 and TIMP1 in diabetic women type II," Research in Molecular Medicine, vol. 2, no. 2, pp. 34-39, 2014.

[90] M. Iranshahy and M. Iranshahi, "Traditional uses, phytochemistry and pharmacology of asafoetida (ferula assafoetida oleo-gum-resin) - a review," Journal of Ethnopharmacology, vol. 134, no. 1, pp. 1-10, 2011.

[91] C.-L. Lee, L.-C. Chiang, L.-H. Cheng et al., "Influenza A $\left(\mathrm{H}_{1} \mathrm{~N}_{1}\right)$ antiviral and cytotoxic agents from Ferula assafoetida," Journal of Natural Products, vol. 72, no. 9, pp. 1568-1572, 2009.

[92] M. Zia-Ul-Haq, S. A. Shahid, S. Ahmad et al., "Antioxidant potential of various parts of Ferula assafoetida L," Journal of Medicinal Plants Research, vol. 6, no. 16, pp. 3254-3258, 2012.

[93] S. M. Bagheri, M. E. Rezvani, A. R. Vahidi et al., "Anticonvulsant effect of Ferula assa-foetida oleo gum resin on chemical and amygdala-kindled rats," North American Journal of Medical Sciences, vol. 6, no. 8, p. 408, 2014.

[94] N. O. Zarmouh, S. S. Messeha, F. M. Elshami et al., "Natural products screening for the identification of selective monoamine oxidase-B inhibitors," European Journal of Medicinal Plants, vol. 15, no. 1, 2016.

[95] Z. Gholamnejad, G. Byrami, M. H. Boskabady et al., "Possible mechanism (S) of the relaxant effect of asafoetida (Ferula assa-foetida) oleo-gum-resin extract on guinea-pig tracheal smooth muscle," 2012. 
[96] M. R. Khazdair, M. H. Boskabady, M. Kiyanmehr et al., "The inhibitory effects of Ferula assafoetida on muscarinic receptors of Guinea-pig tracheal smooth muscle," Jundishapur Journal of Natural Pharmaceutical Products, vol. 10, no. 3, 2015.

[97] M. Kiyanmehr, M. H. Boskabady, M. R. Khazdair et al., "Possible mechanisms for functional antagonistic effect of Ferula assafoetida on muscarinic receptors in tracheal smooth muscle," Malaysian Journal of Medical Sciences, vol. 23, no. 1, pp. 35-43, 2016.

[98] M. R. Khazdair and M. H. Boskabady, "The relaxant effect of Ferula assafoetida on smooth muscles and the possible mechanisms," Journal of HerbMed Pharmacology, vol. 4, no. 2, 2015.

[99] M. Aqel, S. Al-Khalil, and F. Afifi, "Effects of a Ferula sinaica root extract on the uterine smooth muscle of rat and Guinea pig," Journal of Ethnopharmacology, vol. 31, no. 3, pp. 291-297, 1991.

[100] M. Aqel, S. Al-Khalil, F. Afifi et al., "Relaxant effects of Ferula sinaica root extract on rabbit and Guinea pig smooth muscle," Journal of Ethnopharmacology, vol. 31, no. 3, pp. 373-381, 1991.

[101] G. Bayrami, M. H. Boskabady, M. Iranshahi et al., "Relaxant effects of asafoetida extract and its constituent umbelliprenin on Guinea-pig tracheal smooth muscle," Chinese Journal of Integrative Medicine, vol. 19, no. 12, pp. 1-6, 2013.

[102] M. Fatehi, F. Farifteh, and Z. Fatehi-Hassanabad, "Antispasmodic and hypotensive effects of Ferula asafoetida gum extract," Journal of Ethnopharmacology, vol. 91, no. 2-3, pp. 321-324, 2004.

[103] S. H. Hejazian, M. H. Dashti, and S. M. Bagheri, "The relaxant effect of seed's essential oil and oleo-gum-resin of Ferula assa-foetida on isolated rat's ileum," Annals of Medical and Health Sciences Research, vol. 4, no. 2, pp. 238-241, 2014.

[104] E. Kassis, S. Fulder, K. Khalil et al., "Efficacy and safety assessments of Ferula assa-foetida L., traditionally used in Greco-Arab herbal medicine for enhancing male fertility, libido and erectile function," The Open Complementary Medicine Journal, vol. 1, no. 1, 2009.

[105] K. Mala, J. Thomas, D. S. Syam, B. Maliakel, and I. M. Krishnakumar, "Safety and efficacy of Ferula asafoetida in functional dyspepsia: a randomized, double-blinded, placebo-controlled study," Evidence-Based Complementary and Alternative Medicine, vol. 2018, Article ID 4813601, 11 pages, 2018.

[106] M. S. Hashemi, M. H. Hashempur, M. H. Lotfi et al., "The efficacy of asafoetida (Ferula assa-foetida oleo-gum resin) versus chlorhexidine gluconate mouthwash on dental plaque and gingivitis: a randomized double-blind controlled trial," European Journal of Integrative Medicine, vol. 29, Article ID 100929, 2019.

[107] S. Tembhurne, S. Feroz, B. More et al., "A review on therapeutic potential of Nigella sativa (kalonji) seeds," Journal of Medicinal Plants Research, vol. 8, no. 3, pp. 167-177, 2014.

[108] C. Durmuskahya and M. Ozturk, "Ethnobotanical survey of medicinal plants used for the treatment of diabetes in Manisa, Turkey," The Open Conference Proceedings Journal, vol. 4, no. 1, pp. 1431-1438, 2013.

[109] A. Nasir, M. Siddiqui, and M. Mohsin, "Therapeutic uses of shoneez (Nigella sativa Linn.) mentioned in unani system of medicine-a review," International Journal of Pharmaceutical and Phytopharmacological Research, vol. 4, pp. 47-49, 2014.

[110] V. Hajhashemi, A. Ghannadi, and H. Jafarabadi, "Black cumin seed essential oil, as a potent analgesic and antiinflammatory drug," Phytotherapy Research, vol. 18, no. 3, pp. 195-199, 2004.

[111] R. Mohebbatia, M. R. Khazdair, S. Karimia et al., "Hepatoprotective effects of combination hydroalcoholic extracts of nigella sativa and curcuma Longa on adriamycin-induced oxidative stress in rat," Journal of Reports in Pharmaceutical Sciences, vol. 6, no. 2, pp. 93-102, 2017.

[112] R. Mohebbati, M. R. Khazdair, and M. Hedayati, "Neuroprotective effects of medicinal plants and their constituents on different induced neurotoxicity methods: A," Journal of Reports in Pharmaceutical Sciences, vol. 6, no. 1, pp. 34-50, 2017.

[113] M. R. Khazdair, "The protective effects of Nigella sativa and its constituents on induced neurotoxicity," Journal of Toxicology, vol. 2015, 2015.

[114] S. Abdel-Shafi, "Preliminary studies on antibacterial and antiviral activities of five medicinal plants," Journal of Plant Pathology and Microbiology, vol. 4, p. 190, 2013.

[115] A. Haq, P. I. Lobo, M. Al-Tufail et al., "Immunomodulatory effect of Nigella sativa proteins fractionated by ion exchange chromatography," International Journal of Immunopharmacology, vol. 21, no. 4, pp. 283-295, 1999.

[116] A. Haq, M. Abdullatif, P. I. Lobo et al., "Nigella sativa: effect on human lymphocytes and polymorphonuclear leukocyte phagocytic activity," Immunopharmacology, vol. 30, no. 2, pp. 147-155, 1995.

[117] M.-H. Boskabady, R. Keyhanmanesh, S. Khameneh, Y. Doostdar, and M.-R. Khakzad, "Potential immunomodulation effect of the extract of Nigella sativa on ovalbumin sensitized Guinea pigs," Journal of Zhejiang University Science B, vol. 12, no. 3, pp. 201-209, 2011.

[118] M. H. Boskabady, N. Vahedi, S. Amery, and M. R. Khakzad, "The effect of Nigella sativa alone, and in combination with dexamethasone, on tracheal muscle responsiveness and lung inflammation in sulfur mustard exposed Guinea pigs," Journal of Ethnopharmacology, vol. 137, no. 2, pp. 1028-1034, 2011.

[119] A. T. Abbas, M. M. Abdel-Aziz, K. Zalata et al., "Effect of dexamethasone and Nigella sativa on peripheral blood eosinophil count, IgG1 and IgG2a, cytokine profiles and lung inflammation in murine model of allergic asthma," The Egyptian Journal of Immunology/Egyptian Association of Immunologists, vol. 12, no. 1, pp. 95-102, 2004.

[120] M. Abdel-Aziz, A. Abass, K. Zalata et al., "Effect of dexamethasone and Nigella sativa on inducible nitric oxide synthase in the lungs of a murine model of allergic asthma," Iranian Journal of Allergy, Asthma and Immunology, vol. 13, no. 5, pp. 324-334, 2014

[121] A. E. A. El Aziz, N. S. El Sayed, and L. G. Mahran, "Antiasthmatic and anti-allergic effects of thymoquinone on airway-induced hypersensitivity in experimental animals," Journal of Applied Pharmaceutical Science, vol. 1, pp. 109117, 2011.

[122] M. El Gazzar, R. El Mezayen, J. C. Marecki, Mark R. Nicolls, A. Canastar, and S. C. Dreskin, "Anti-inflammatory effect of thymoquinone in a mouse model of allergic lung inflammation," International Immunopharmacology, vol. 6, no. 7, pp. 1135-1142, 2006.

[123] H. Hosseinzadeh, M. Eskandari, and T. Ziaee, "Antitussive effect of thymoquinone, a constituent of Nigella sativa seeds, in Guinea pigs," Pharmacologyonline, vol. 2, pp. 480-484, 2008.

[124] B. M. Hossein, V. Nasim, and A. Sediqa, "The protective effect of Nigella sativa on lung injury of sulfur mustard- 
exposed Guinea pigs," Experimental Lung Research, vol. 34, no. 4, pp. 183-194, 2008.

[125] N. M. A. Ameen, F. Altubaigy, T. Jahangir et al., "Effect of Nigella sativa and bee honey on pulmonary, hepatic and renal function in Sudanese in Khartoum state," Journal of Medicinal Plants Research, vol. 5, no. 31, pp. 6857-6863, 2011.

[126] U. Kalus, A. Pruss, J. Bystron et al., "Effect of Nigella sativa (black seed) on subjective feeling in patients with allergic diseases," Phytotherapy Research, vol. 17, no. 10, pp. 1209-1214, 2003.

[127] A. M. Salem, A. O. Bamosa, H. O. Qutub et al., "Effect of Nigella sativa supplementation on lung function and inflammatory mediators in partly controlled asthma: a randomized controlled trial," Annals of Saudi Medicine, vol. 37, no. 1, pp. 64-71, 2017.

[128] A. H. Gilani, N. Aziz, I. M. Khurram et al., "Bronchodilator, spasmolytic and calcium antagonist activities of Nigella sativa seeds (Kalonji): a traditional herbal product with multiple medicinal uses," Journal of Pakistan Medical Association, vol. 51, no. 3, pp. 115-120, 2001.

[129] M. Boskabadi and B. Shirmohammadi, "Effect of Nigella sativa on isolated guinea pig trachea," 2002.

[130] M. Boskabady, S. Kiani, and P. Jandaghi, "Stimulatory effect of Nigella sativa on $\beta 2$-adrenoceptors of Guinea pig tracheal chains," Medical Journal of The Islamic Republic of Iran (MJIRI), vol. 18, no. 2, pp. 153-158, 2004.

[131] H. Boskabady, R. Keyhanmanesh, and M. A. E. Saadatloo, "Relaxant effects of different fractions from Nigella Sativa L. on guinea pig tracheal chains and its possible mechanism (S)," Indian Journal of Experimental Biology, vol. 46, no. 12, pp. 805-810, 2008.

[132] M. H. Boskabady, R. Keyhanmanesh, S. Khamneh et al., "The effect of Nigella sativa extract on tracheal responsiveness and lung inflammation in ovalbumin-sensitized Guinea pigs," Clinics, vol. 66, no. 5, pp. 879-887, 2011.

[133] R. Keyhanmanesh, H. Bagban, H. Nazemiyeh et al., "The relaxant effects of different methanolic fractions of Nigella sativa on Guinea pig tracheal chains," Iranian Journal of Basic Medical Sciences, vol. 16, no. 2, p. 123, 2013.

[134] S. Niazmand, E. Fereidouni, M. Mahmoudabady, and S. M. Mousavi, "Endothelium-independent vasorelaxant effects of hydroalcoholic extract from nigella sativa seed in rat aorta: the roles of $\mathrm{Ca}^{2}$ and $\mathrm{K}^{+}$channels," BioMed Research International, vol. 2014, Article ID 247054, 7 pages, 2014.

[135] M. Boskabady, N. Mohsenpoor, and L. Takaloo, "Antiasthmatic effect of Nigella sativa in airways of asthmatic patients," Phytomedicine, vol. 17, no. 10, pp. 707-713, 2010.

[136] V. Hadi, S. Kheirouri, M. Alizadeh et al., "Effects of Nigella sativa oil extract on inflammatory cytokine response and oxidative stress status in patients with rheumatoid arthritis: a randomized, double-blind, placebo-controlled clinical trial," Avicenna Journal of Phytomedicine, vol. 6, no. 1, p. 34, 2016.

[137] W. Barlianto, M. Rachmawati, M. Irawan et al., "Effects of Nigella sativa oil on Th1/Th2, cytokine balance, and improvement of asthma control in children," Paediatrics in Indonesia, vol. 57, no. 5, pp. 223-228, 2017.

[138] W. Barlianto, D. Wulandari, M. Chusniyah et al., "Improvement of th17/treg balance and asthma control test score by Nigella sativa supplementation in asthmatic children: a new approach to managing asthma," Turkish Journal of Immunology, vol. 6, no. 1, pp. 1-7, 2018.

[139] M. Rashidmayvan, M. Mohammadshahi, S. S. Seyedian et al., "The effect of Nigella sativa oil on serum levels of inflammatory markers, liver enzymes, lipid profile, insulin and fasting blood sugar in patients with non-alcoholic fatty liver," Journal of Diabetes \& Metabolic Disorders, vol. 18, no. 2, pp. 453-459, 2019.

[140] M. Darand, Z. Darabi, Z. Yari et al., "The effects of black seed supplementation on cardiovascular risk factors in patients with nonalcoholic fatty liver disease: a randomized, doubleblind, placebo-controlled clinical trial," Phytotherapy Research, vol. 33, no. 9, pp. 2369-2377, 2019. 